\title{
Support by migrants to their elderly parents in rural Cambodia and Thailand: A comparative study
}

Zachary Zimmer

Kim Korinek

John Knodel

Napaporn Chayovan

Follow this and additional works at: https://knowledgecommons.popcouncil.org/departments_sbsr-pgy

Part of the Demography, Population, and Ecology Commons, Gerontology Commons, International Public Health Commons, and the Migration Studies Commons How does access to this work benefit you? Let us know!

\section{Recommended Citation}

Zimmer, Zachary, Kim Korinek, John Knodel, and Napaporn Chayovan. 2007. "Support by migrants to their elderly parents in rural Cambodia and Thailand: A comparative study," Poverty, Gender, and Youth Working Paper no. 2. New York: Population Council. 


\section{POVERTY, GENDER, AND YOUTH}

\section{Support by Migrants to Their Elderly Parents in}

Rural Cambodia and Thailand: A Comparative Study

Zachary Zimmer, Kim Korinek, John Knodel, and Napaporn Chayovan 


\section{(2) Population Council}

One Dag Hammarskjold Plaza

New York, New York 10017 USA

www.popcouncil.org pubinfo@popcouncil.org

Our new name Beginning with the first number of 2007, Policy Research Division working papers are now called Poverty, Gender, and Youth working papers. For information on papers in both series, including those that are available for downloading in PDF format, see www.popcouncil.org/publications/wp/index.html

This material may not be reproduced without written permission from the authors.

ISSN: $1554-8538$

(C) 2007 The Population Council, Inc. 


\section{Support by Migrants to Their Elderly Parents in Rural Cambodia and Thailand: A Comparative Study}

Zachary Zimmer, Kim Korinek, John Knodel, and Napaporn Chayovan

Zachary Zimmer is Senior Scholar, Institute of Public and International Affairs, and Professor of Sociology, University of Utah. Kim Korinek is Assistant Professor of Sociology, University of Utah. John Knodel is Research Scientist, Population Studies Center, and Professor Emeritus in Sociology, University of Michigan. Napaporn Chayovan is Professor, College of Population Studies, Chulalongkorn University. This paper was initially presented at the 2007 Annual Meeting of the Population Association of America, New York, 29 March. The research was supported by grants from the Hewlett Foundation and the Institute of Public and International Affairs, University of Utah. 


\begin{abstract}
Internal migration in Southeast Asia raises questions about strains upon traditional systems of support for older adults. While remittances to parents' households play a role in rural household economies, uncertainty remains regarding whether and under what circumstances children interact with their elderly parents. This paper focuses on the adult children of older persons living in rural Cambodia and Thailand and examines the determinants of personal visits, monetary remittances, and more general forms of household support. Analyses consider ways in which geographically distant children support parents, the extent to which characteristics of parents, children, and households enhance or detract from these intergenerational interactions, and how determinants of intergenerational interaction vary between the two countries. Comparisons between countries of conditions and characteristics of families provide insights into how social, economic, and cultural forces motivate provision of support to aging parents.
\end{abstract}


The late twentieth century has witnessed remarkable demographic and economic changes in most parts of the developing world, including Southeast Asia. These changes pose a number of challenges for older adults. For instance, declines in fertility, in some cases more rapid and pervasive than expected, brought fertility levels close to, and often below, replacement in many countries (Bongaarts 2002). Consequently, the absolute and relative size of the elderly population has begun to grow (Sagaza 2004; Sokolovsky 2001). Moreover, rapid urbanization, a by-product of social and economic development and of changes in labor and industry, and the subsequent out-migration of young adults from rural villages, have exacerbated population aging in rural areas (Knodel and Saengtienchai 2007; Kreager 2006; Watkins and Ulack 1991). The corresponding rise in elderly dependency ratios in rural communities of Asia, and the potential implications that this may have for the support of older adults, have led some to suggest that a potential catastrophe is looming (Chan 1999; Phillips 2000; UN 1999; World Bank 1994).

The voices of alarm reflect questions and concerns about how a more mobile and modernizing working-age population will be equipped to provide the material and physical support to an expanding population of older adults who continue to live in rural Asia. Traditionally, Asian societies have relied heavily on intergenerational familial exchanges as a means of supporting the older generation, with resource transfers flowing toward older, dependent parents (Mason 1992). These family-based systems of support are premised upon the assumption that older adults have one or more living children, that at least one or more coreside or live nearby, and that they will behave in a filial manner (Smith 1998). Yet, anecdotal evidence increasingly points to a breakdown of support systems. It is thought that the structural transformations occasioned by population aging, urbanization, and development undermine traditional, family-based systems of support and security for the elderly in places where formal support structures are weak. But, while macrolevel demographic and socioeconomic shifts justify concerns about intergenerational support systems, the impact of migration on family support networks have only begun to be examined systematically. It is still difficult to deduce whether, and under what circumstances, "migration is a cause of vulnerability in old age" (Kreager 2006: 38-39).

The current study focuses on several questions that cover a broad range of relevant issues. First, to what extent are older adults in rural areas being abandoned? Second, what are the characteristics of migrating children, and do they differ from those of children who live closer to aging parents? Third, do interactions between adult children and their elderly parents differ depending upon residential proximity? Fourth, what are the determinants of specific types of intergenerational interactions? We address these questions with respect to adult children and their older parents living in Cambodia and Thailand. The value of comparative research for understanding the well-being of older adults has been illustrated in a number of recent publications (Albert and Cattell 1994; Bengtson et al. 2000; Chi, Chappell, and Lubben 2001; Frankenburg et al. 2002; Liang et al. 1991; Melzer et al. 2004; Minicuci et al. 2004; National Research Council 2001; Su and Ferraro 1997). These writings underscore the benefits of comparative research for highlighting the diversity in aging across cultures and geographic locations. 
In addition to investigating support provided by migrating children, the contrast between Cambodia and Thailand allows us to examine the implications of cultural norms versus economic and demographic realities for the well-being and support of older adults in rural areas. Cambodia and Thailand share a common geography and many aspects of culture, such as bilateral kinship systems and popular Buddhism. Yet, they differ widely with respect to living standards, demographic background, and historical circumstances. Thailand has experienced particularly rapid economic growth, and the social implications of this development have been wide ranging. Fertility in Thailand fell sharply since the late 1960s to below replacement by the 1990s, while fertility in Cambodia has remained high, with total fertility rates above 5 until shortly before 2000 (United Nations 2005a). Although Cambodia has not experienced the same level of economic growth as Thailand, the country has seen some recent expansion of its garment industry in and around the capital city, Phnom Penh. The lack of economic progress in Cambodia is at least in part an aftermath of years of civil war and the brutal and genocidal Khmer Rouge regime that controlled the country in the 1970s (Chandler 2000). The Khmer Rouge period has had other long-term impacts that affect the nature and quality of support for older adults. For instance, high mortality during the period has led to depletion of sources of support for today's older adults (Zimmer et al. 2006).

Our dataset for Thailand is from 1995; therefore it was collected prior to the economic crisis of 1997 and immediately following an extended period of rapid economic growth. The data for Cambodia were collected in 2004. With respect to labor migration, even in 1995 opportunities for rural working-age adults in Thailand to find employment outside the agricultural sector, especially in urban areas, were greater than they are in Cambodia today. In Thailand the population that lived in urban areas had reached 30 percent by 1995, up from less than 20 percent in 1960, while in Cambodia those living in urban areas in 2004 still constituted less than 20 percent of the population (UN Population Division 2007). According to the UNDP (2007), the human development index in 1995 for Thailand (.751) far exceeded the level reached in 2004 for Cambodia (.583). That Thailand's level of economic development in 1995 was far more advanced than in Cambodia nine years later, and that Thailand's older population benefited from this situation, are reflected in the statistics on household amenities in our two datasets. In 1995, 97 percent of persons aged 60 and older in Thailand lived in households with electricity, compared to only 31 percent in 2004 in Cambodia; 96 percent of Thai elderly households had a toilet in 1995, compared to only 45 percent of Cambodian elderly households in 2004 (Knodel forthcoming). Likewise, vast differences are apparent in household possessions. For example, over half of Thai households with elderly residents had a refrigerator and almost half had a motorcycle in 1995, while only 4 percent of elderly Cambodians lived in households with a refrigerator and only 30 percent had a motorcycle in 2004.

Migrant remittances have been examined in Thailand from a variety of perspectives, including that of migrants and their parents (e.g., Knodel and Saengtienchai 2007; Korinek and Entwisle 2006; Osaki 2003; Vanwey 2004). Other types of interaction between migrant children and parents have been studied less frequently. In the case of 
Cambodia, the residential arrangements and support relations that link elderly adults and their adult children remain largely unknown. By formulating a comparative perspective, we identify common and distinctive approaches that emerge in the face of population migration (Lowenstein and Daatland 2006). Moreover, cross-national comparison of intergenerational interactions provides insights for refining theoretical perspectives on the social, economic, and cultural forces that motivate migrants to remit earnings and otherwise extend assistance to their households of origin and aged parents.

\section{Background and Theoretical Perspective}

In countries like Cambodia and Thailand, where formal means of old-age assistance are weakly developed, socioeconomic and demographic changes have the potential to drive shifts in intergenerational interactions (Aboderin 2005; Sokolovsky 2001). For instance, migration has been shown to have substantial impacts on living arrangements of elderly persons in the developing world (United Nations 2005b), while internal and crossborder migrations have raised concerns that traditional modes of social and economic support will be eroded through diminished social contact and decay of normative patterns of filial obligation (Apt 2000; Chan 1999; Hermalin 2002a). Some scholarly and popular writings have suggested that older adults are increasingly being abandoned by their mobile, independent children (Apt 2000; Charasdamrong 1992; French 2006; United Nations 2002). Research in China (Ikels and Beall 1993) has suggested that intergenerational contracts mandating parental support by sons have been weakened by the pull of urban labor markets, a decline in psychological and material incentives to offer support, and the erosion of village social controls to penalize neglectful children. Studies in other parts of the developing world have raised similar concerns (e.g., Goldstein et al. 1983; Watkins and Ulack 1991). These sentiments echo a prominent notion among Western social scientists and gerontologists that modernization contributes to abandonment of older people by their families (Aboderin 2004).

A contrasting body of literature paints a less dire picture (Knodel and Saengtienchai 2007). Rather than focusing solely on negative aspects, this research illuminates both the detriments and benefits of demographic change and migration for older adults (Mason 1992). These studies suggest that, even in settings of modernization, urbanization, and population mobility, it is the exceptional few elderly who are completely abandoned. Migration may rather reflect a household economic strategy that produces benefits (Itzigsohn 1995; Stark and Bloom 1985; Stark and Lucas 1988). Although less pervasive than in decades past, coresidence with adult children remains common in many countries of Southeast Asia, even in the midst of heightened mobility and urbanization (Chan 2005; Frankenberg et al. 2002; Knodel and Debavalya 1997; Knodel et al. 2005a; Ofstedal et al. 1999). Attitudinal research demonstrates strong, widespread adherence to the idea that children's primary responsibility is to care for their elderly parents (Wongsith 1994). Even when they migrate great distances from home, adult children may continue to be a source of valuable information and monetary remittances (Velkoff 2001). Thus, despite demographic transformations that influence living arrangements, filial loyalty and inter- 
generational transfers may continue to be the prominent bases of elderly support systems across a wide range of Asian societies (Ofstedal, Knodel, and Chayovan 1999). As Kreager (2006: 56) explains, the combination of population aging and population mobility has "intricate and varied welfare implications," which can only be understood through analysis of the economic and support relationships in which elderly adults are involved.

Continued helpful intergenerational interaction after migration reinforces an altruistic framework that has often been used to elucidate children's remittance patterns to parental households. Altruism assumes a cooperative familial organization and a mutual concern for family members that provide insurance in the face of risk or crisis (Becker 1974). Remittances and other forms of support are offered out of concern for the welfare of family members toward whom an individual feels a sense of filial obligation or affinity. If migrant children are part of a cooperative family-based arrangement that aims to ensure the welfare of all members, then not all migrant children will support parents to the same extent, with equal regularity, or in similar ways. Rather, interactions with parents will be moderated by life circumstances faced by the migrant, the supportive acts of other family members, and older parents' needs for support and assistance. Children's propensity to support parents will be further conditioned by societal expectations and cultural norms, as is reflected in the gender disparities in remittances and parental support observed in some settings (Curran 1996; Osaki 2003; Vanwey 2004). Where altruism motivates transfers, circumstances indicative of need should be positively associated with the receipt of transfers in the form of remittances and/or instrumental support (Frankenberg et al. 2002; Kaufman and Lindauer 1986; Lee et al. 1994; Massey and Basem 1992). Altruistically motivated transfers, it is argued, are more important for households in lowincome settings, and in these settings one is more likely to provide support to a family member whose income has fallen below a threshold level (Diaz and Echevarria 2002).

Related to an altruistic point of view is a vulnerabilities framework that recognizes risk in old age as being highly variable. Rather than treating chronological age as indicative of dependency and disablement for all older adults, or presuming that rising rates of old-age dependency represent a demographic crisis, the framework advocates attending to subgroups of older adults defined by characteristics indicative of social status, income security, family structure, social networks, physical health, and other traits related to dependence (Kreager 2006: 41; Schröder-Butterfill and Marianti 2006a). An older adult's vulnerability and need for support are linked to factors such as their incomegenerating potential, physical health, and current living situation. For example, although widowhood often implies loss of an important social tie and loss of an economically productive spouse, the degree of vulnerability associated with widowhood depends on other factors - such as whether the widow or widower is impoverished or childless, whether he or she coresides with children or other relatives, and his or her physical functioning capabilities (Drèze 1990; Mason 1992; Sengupta and Agree 2002; Sokolovsky 2001). Moreover, a circumstance likely to affect the provision of material assistance is that the adult children of the neediest older adults may be the least well-off themselves; that is, there is likely an intergenerational transmission of poverty. 
Although frequently discussed within these frameworks, the health and disability status of aged parents has not often been addressed in analytical models predicting remittances or other types of intergenerational support. It is especially important to take into account an elderly parent's experience with physical disabilities that may inhibit both productive employment and self-care. Several studies (Frankenberg et al. 2002; Kreager 2006; Petrova 2003) have shown that health and healthcare crises are salient factors influencing patterns of children's coresidence and intergenerational support. Thus, the need for both remittances and instrumental support will be heightened for the elderly who physical difficulties in performing daily activities. Not only is the ability to perform productive labor curtailed, but parents may require assistance to complete activities necessary for daily survival, such as bathing and eating. The experience of physical disability, especially when elderly parents lack local social and economic resources, is a form of vulnerability to which altruistically motivated children will respond.

In the current paper, we begin descriptively, examining the extent to which migration of adult children results in older adults being abandoned in rural areas, the residential location of adult children vis-à-vis their parents, and several forms of intergenerational interaction depending upon residential location of adult children. We then assess factors that promote these various types of interaction. The perspective we adopt, which combines the altruistic and vulnerability frameworks, leads us to hypothesize that children respond to perceived levels of dependence and need experienced by elderly parents. Therefore, when parents live in isolation and their capacity for performing productive labor or generating income is restricted, the probability of visits, remittances, and household support is heightened. The altruistic framework further suggests that support is generated in a cooperative way; therefore intergenerational interaction is additionally a function of an adult child's own social circumstances and characteristics. Moreover, the presence of other kin, in particular a migrant's working-age siblings, alleviates pressures to provide support. Consequently, parents, even when children have migrated, are thought to receive support and care through a variety of flexible coresidential and economic arrangements. We also suspect that it will be a rare occasion in which older parents are completely abandoned.

The comparative aspect of our analysis is also a focal point. Because socioeconomic conditions were more favorable in Thailand in 1995 than in Cambodia in 2004, we expect remittances to be more substantial in the former. We hypothesize, however, that despite differences in actual levels of remittances, associations between parents' dependence and vulnerability and the tendency to provide support are similar in the two countries.

\section{DATA AND Measures}

The comparative strategy we adopt is made possible by parallel surveys conducted in the neighboring countries of Cambodia and Thailand. Although the surveys are nine years apart, they employed similar lines of questioning and schemes of categorization. For Thailand, data are from the 1995 Survey of the Welfare of Elderly in Thailand 
(SWET). SWET involved a national probability sample of 7,708 individuals aged 50 years and older in private households who were usual residents of the household. The data have been used in a number of other studies (e.g., Hermalin 2002b; Knodel and Chayovan 2001; Knodel and Chayovan 1997; Sobieszczyk, Knodel, and Chayovan 2003; Zimmer and Chayovan 2000). Detailed information on the survey methodology is available in these publications as well as in a SWET general report (Chayovan and Knodel 1997). For Cambodia, data are from the 2004 Survey of the Elderly in Cambodia (SEC). Conducted in 2004, the SEC features a representative sample of 1,273 persons 60 and older residing in six provinces, including Phnom Penh. The six provinces are the most populated in the country and together contain over half of Cambodia's population. The SEC provides information on aspects of aging, material support, and well-being particular to Cambodia's experience with civil war, genocide, and other forms of violence and conflict. Detailed information on survey methodology and sample characteristics is provided elsewhere (e.g., Knodel et al. 2005b; Zimmer et al. 2006).

In order to keep the analysis comparative, we confine the SWET sample to those 60 and older. In addition, the analysis concerns only older adults living in rural areas who have at least one child aged 16 and older. The presence of children 16 and older is used to delineate our sample since survey results indicate that departures from the parental household begin at about the time children reach this age. Only small minorities of older Thais and Cambodians have no children aged 16 and older. ${ }^{1}$ These criteria limit the sample size to 3,202 older persons in Thailand and their 17,517 adult children and to 777 older persons in Cambodia and their 3,751 adult children.

The two surveys interviewed older persons, using separate rosters to gather information about children, both resident and nonresident. Older adults were asked where each of their living children currently resides. Responses were used to classify children's residential locations and proximity to the parental household. Specifically, each living child aged 16 and older was coded as coresident, living next door, living in the same village, living in the same province, or living outside the province. Given their similar degrees of proximity to parents and the likelihood of daily interaction, we combine those coresiding and living next door into a single category, which we call living nearby. A great majority of those living nearby actually coreside. Specifically, the 777 rural Cambodians who have at least one child aged 16 and older have 993 coresident children and 119 living next door. The 3,202 rural Thais have 3,063 coresident children aged 16 and older and 1,923 living next door. Both surveys include additional delineations for living within the same district or commune, and living outside the country.

Given the complex patterns of circular, seasonal, and return migration that are often characteristic of rural populations in Southeast Asia, identifying mobile individuals as migrants can be problematic (Bell et al. 2002). The continuum of parent-child geographic proximity encapsulates varying degrees of interpersonal contact with, and individual mobility from, the parental household. In this study we define an adult child as a migrant if he or she resides in another province or country. In both surveys adult children living outside the province are designated as migrants irrespective of their length of absence from the parental household. By describing the patterns of support and interaction provided by 
children who are migrants in a conventional sense, as well as by those living at varying distances from their parental households, we illustrate how different types of child residential mobility affect intergenerational interactions and, potentially, parental well-being.

We examine three types of interaction that take place between children aged 16 and older and their parents. The first is personal visits. Elderly respondents in Cambodia and Thailand were asked the frequency with which each child not living at home visits. We dichotomize the measure into those visiting at least monthly and those visiting less frequently. Second is a measure of cash support. Respondents in both countries were asked whether a child gives money directly to the older adult. If the answer was yes, respondents were asked to estimate the amount given. Using this follow-up question, we are able to distinguish between those giving any money to parents and those giving a more substantial amount. A substantial amount is considered to be at least 100,000 Riels in Cambodia and 1,000 Baht in Thailand per year. Both amounts were equal to about US\$25 at the time the surveys were conducted. It is difficult to assess the meaning of very small and insignificant amounts of money changing hands, thus we define giving money as giving an amount equivalent to US\$25 or more per year. The third type of interaction is a more general measure of support. In Cambodia, respondents were asked whether the child provides general household support, presumably including both monetary and other material forms. This measure is dichotomously coded. In Thailand, there was no direct question on general household support, but respondents were asked whether a child provides food or goods to parents and, if so, how regularly. The question was asked only about non-coresident children. The most common frequency with which non-coresident children were reported giving food or goods was one to three times a year, undoubtedly reflecting token gifts of food that children commonly bring with them on a visit during a holiday and thus not constituting substantial support of the household. On the other hand, the frequent provision of food and similar goods would represent a significant contribution and thus could be equated with general household support. While we do not compare these two items directly between surveys, we use them to delineate a measure of non-cash support to parents and/or their household. We dichotomize the measure in Thailand as those providing this type of support at least monthly and others.

The aforementioned altruism and vulnerabilities frameworks suggest that the probability of interaction with parents is a function of a number of characteristics, including some that relate to the migrant child's ability to provide support, and some that indicate the parents' level of dependence and vulnerability. Variables representing these factors are included in multivariate equations where we examine the determinants of interactions from the perspective of the migrant child. For migrant children we consider age, sex, level of education, marital status, and number of own children. We expect those with higher education and fewer children of their own to have greater means with which to support parents. Older children and those who are married may have greater resources, but may also have more competition for these resources - for example, from in-laws. These variables are coded categorically or dichotomously depending on the available information. 
For parents, we first consider age and sex. Marital status is measured as spouse present or absent. Education is measured dichotomously as none versus any formal education. Main lifetime occupation is considered as working in agriculture or some other sector (including never worked), and work status as having worked in the past year versus not. Those without education and not working are likely to be more vulnerable. Parents in agriculture may also be more vulnerable if the alternative is work in a type of occupation that affords greater lifetime security. Yet, agriculture may also provide some current means of subsistence if the individual or other household members are still engaged in agricultural work.

Several standard disability questions were asked based on activities of daily living, or ADLs (Katz et al. 1963). Ability to eat, dress, and bathe oneself were included in both the Cambodia and Thailand surveys. The fourth disability item differed between surveys. In Cambodia it assessed ability to get up from bed unassisted; in Thailand it assessed ability to walk around the house unassisted. For both countries we created a variable indicating number of disabilities reported by summing the items with which a respondent reports any difficulty in conducting the task; thus it has a minimum value of 0 and a maximum value of 4 . The assumption is that having a greater number of ADL difficulties represents a higher level of disability, which in turn indicates more vulnerability and greater need.

Also measured continuously is the total number of children living outside the province. Adult children whose parents have a large number of other migrant children may not feel as compelled to provide support if responsibility for that support is distributed among siblings living outside the province.

Finally, we include a categorical measure for coresidence status with children and grandchildren. Having children nearby (i.e., coresident or living next door) is the comparison category. Other categories include having both children nearby and grandchildren coresident; having only grandchildren coresident (that is, living in a so-called skippedgeneration household); and having neither children nearby nor grandchildren coresident. ${ }^{2}$ We assume that parents without children nearby would have a higher level of vulnerability and therefore require greater support from a migrant child. Both living with grandchildren only and living without children or grandchildren can represent vulnerable situations. In the former instance, in supporting the household, migrant children may be supporting both their parents and their own children, if indeed the grandchild is the migrant's child. In some cases, the grandchild, if old enough, may contribute to household support and thus lessen the vulnerability of older adults.

\section{RESULTS}

\section{Are older adults in rural areas being abandoned by their children?}

In Table 1 we address the concern that migrant children leave parents physically isolated in rural areas by considering older parents as units of analysis. The first panel shows that, in both Cambodia and Thailand, 83 percent of older adults report having an adult child nearby — defined as being in the same household or next door. In rural Thai- 
land, as compared to rural Cambodia, a greater share of older adults report having children living in each of the other three categories, including outside the province. The greater proportion of Thai parents with a child in each of these other residential categories can be partially explained by the fact that Thai parents have a greater number of living adult children on average than Cambodian parents (5.65 vs. 5.04). In turn, this disparity in part reflects the decades of violence and war in Cambodia during which many adults, now elderly, experienced the death of spouses and children (Huguet et al. 2000; Zimmer et al. 2006). The higher percentage of rural Thai elderly with a child outside the province also likely reflects more extensive employment opportunities for migrants to urban areas.

The second panel, which shows where the nearest child lives vis-à-vis the elderly parent, indicates that in most cases where an adult child does not live nearby, he or she lives in the same village. In Cambodia, only about 5 percent of older adults report having no children nearby or in the village, and for just 2 percent the nearest child lives outside the province. The corresponding proportions are only slightly higher in Thailand.

The third panel indicates that the chances of having a child living nearby do not change even if the older adult has one or more children living outside the village or outside the province. For instance, almost 80 percent of older adults in both Cambodia and Thailand who have a child living outside the province report at least one child living nearby. It appears, then, that older adults who have migrant children are very likely to have a number of children, one or more of whom live nearby.

This last point is taken a step further in the fourth panel, which indicates the relationship between an older adult's total number of children and the location of the nearest child. In both countries, elderly parents with fewer children are more likely to have their nearest child living outside the province: 16 percent of parents in Cambodia and 17 percent in Thailand with only one living adult child report that this child lives outside the province. But very few older adults in either sample report having only one living adult child. (As noted earlier, the small number of Thais and Cambodians who have no children aged 16 and older are excluded from all analyses.) Many older adults in rural Thailand and Cambodia have five or more adult children, and, among those with greater numbers, the chances of having the nearest child living outside the province are very small.

None of these findings provides evidence of substantial parental abandonment in either country with respect to geographic proximity to adult children. Moreover, despite their demographic, economic, and historical circumstances, the rural elderly in Thailand in 1995 and Cambodia in 2004 are fairly similar with respect to their residential proximity to adult children.

Table 2 shows the percent distribution of living arrangements of elderly parents who have adult migrant children living outside the province. ${ }^{3}$ In Cambodia, 25 percent of parents of children who live outside the province live with a spouse, at least one other adult child, and at least one grandchild. About the same proportion of parents do not live with a spouse but live with an adult child and a grandchild. Only about 2 percent live without a spouse, child, or grandchild, and an additional 5 percent live without a spouse or child but with a grandchild. 
The distribution is somewhat different in rural Thailand. A larger proportion live with a spouse only (17 percent in Thailand versus 9 percent in Cambodia), and a smaller proportion live with children and grandchildren but no spouse (15 percent in Thailand compared to 26 percent in Cambodia). These divergent patterns are likely linked, in part, to Cambodia's recent history of war and related violence, which led to very high rates of mortality and widowhood (Zimmer et al. 2006). A small proportion of rural Thai parents live without a spouse, child, or grandchild (6 percent) or with a grandchild only (1 percent). Table 2 indicates, then, that very few migrant children have elderly parents who live alone or without a spouse or a nearby adult child.

\section{What are the characteristics of migrant children?}

Given their relatively high levels of completed fertility, even though elderly parents in rural Thailand and Cambodia are likely to have an adult child living nearby, they are also likely to have a child living outside the province. From the perspective of adult children, then, a sizable number have an elderly parent from whom they are separated by a large geographic distance. About 20 percent of children in rural Cambodia and 29 percent in Thailand have migrated outside their parents' province. Again, it is likely that the greater proportion of migrant children in Thailand reflects a greater prevalence of employment opportunities in urban areas.

Table 3 conveys an important association between sibship size and place of residence vis-à-vis elderly parents. First, in both countries, there is a consistent inverse association between sibship size and the probability of living near one's older parents. In Cambodia, 77 percent of children without siblings live near their parents, whereas only 26 percent of those who have at least four siblings live nearby. Similarly, in Thailand, the proportion declines from 69 percent to 27 percent as sibship size increases from one to five or more. The drop in the percent who live nearby is especially pronounced between sibship sizes of one and two, suggesting that consideration of leaving a parent with no adult child nearby may be an important deterrent to moving. Second, in both countries, children in larger sibships are more likely to live outside their parents' province. This tendency is notably stronger in Thailand than in Cambodia.

Additional results in Table 3 further illustrate that the propensity of adult children to migrate from rural provinces is influenced by life circumstances and sociodemographic characteristics. In both Cambodia and Thailand, sons are more likely to live at a distance from their parents, while daughters are more likely to live nearby. This pattern in part reflects cultural norms whereby daughters, more so than sons, are expected to coreside with and provide support to elderly parents (Knodel and Ofstedal 2002; Zimmer and Kim 2001). We also observe an association between age and residential proximity that is country-specific. In both countries younger adults, between ages 16 and 24 , are more likely to live nearby their older parents than are other adult children. This is no doubt because younger adults are less likely to be married and therefore less likely to have set up independent households. When it comes to migrating outside the province, however, Cambodian and Thai children differ. In Cambodia, the youngest 
adults in the sample (i.e., those ages 16 to 24) are least likely to be living outside the province, while in Thailand there is an inverse association between age and living outside the province. Hence, young adults who migrate do so earlier in Thailand than in Cambodia. Again, this may be the result of greater educational and employment opportunities in Thailand.

Adult children with high levels of education are most likely to be living outside their parents' province. In Cambodia, one-quarter or fewer with less than a college education live outside the province, compared to about 50 percent of those with a college education. The percent of college-educated children living outside the province is similar in Thailand. Highly educated adults are likely to leave their parents' rural villages to take advantage of educational opportunities, and, once educated, seek suitable employment opportunities, also outside their parents' rural provinces. Therefore, despite the possibility of differences in educational opportunities between the two countries, once adult children have attained a college education, they are equally likely to migrate.

In both countries, children living near their parents are less likely to be married than those who have migrated outside the province. However, the probability of living outside the province is higher among married children in Cambodia and nonmarried children in Thailand. Recent research conducted among Thai migrants has demonstrated that labor migration has become a common premarital life course event, one that tends to hasten the transition to marriage among young adults in certain regions of rural Thailand (Mills 1999; Jampaklay 2006). In rural Cambodia, where urban labor market opportunities are not as developed as in Thailand, migration out of rural provinces appears to be undertaken more frequently by adults who have already married. In both countries adult children without children of their own are more likely to be living nearby. Both of these results suggest that the decision about whether and when to migrate are influenced by life circumstances.

In both countries, then, children with more siblings are more likely to be migrants than those with fewer siblings. This result, together with the fact that children without siblings are by far the most likely to live near their parents, suggests that decisions by children to migrate outside the province may be dependent on parents' living situation.

\section{Do interactions with parents in rural areas differ by residential proximity?}

Table 4 displays the percent of adult children, according to proximity of residence, who visit their parents at least monthly and give money (equivalent to at least US $\$ 25$ yearly) to their parents. In both countries, the tendency to visit declines the further away the child lives. In contrast, the tendency to give money is highest among those living outside the province. This relationship supports the idea that adult children living outside the province are more likely to be adequately employed in wage work than those who have remained closer to the parental household. Such children therefore may be better able to garner the resources necessary for sending money back to their household of origin. It may also suggest a household strategy of sending an adult child into out-of- 
province employment in order to earn income that can be used by the family in the rural village.

Although migrant children in Thailand regularly give money to their parents, this is not true not in Cambodia, a result that likely is a function of relative economic circumstances. For instance, about 45 percent of children in Thailand who live outside their parents' province remit at least US\$25 per year to their parents, compared with only 11 percent in Cambodia. Clearly, given the country's lower living standard and earnings level, remitting US\$25 per year represents a greater financial burden for Cambodian workers.

In contrast, adult children in Cambodia are much more likely to provide general household support. Such support may include food or clothing, and may be of any value. Nearly half of those living outside the province provide this type of support. In Thailand, we examined a more narrow definition of general support - the provision of food or goods. Children living near their parents provide this sort of support more frequently than those living farther away.

Overall, the results indicate frequent interaction between parents and children, irrespective of residential proximity. The nature of interaction diverges, however, according to the degree of parent-child residential proximity. In both settings regular visits are more common by those children living in closer proximity, and provision of money is more common among those living farther away.

Table 5 further examines interactions with older parents in rural areas by illustrating the extent to which particular interactions occur alone or in combination. For instance, we examine whether children who visit are also more likely to give money or provide general support. Results indicate that among migrant children, one type of interaction with parents tends to be strongly and positively related to others. For instance, in Cambodia, nearly 70 percent of children who visit at least monthly also provide general household support, while only about 38 percent of those who do not visit monthly provide such support. The association between visiting and the provision of food or goods appears to be especially strongly connected in Thailand. Seventy-two percent of those who visit at least monthly also provide food or goods, compared to only about 12 percent of those who do not visit. These results are further indication that although having an adult child living outside the province has become quite common for the rural elderly in Thailand and Cambodia, these migrant children have not abandoned their parents, but rather tend to provide multiple forms of support on a regular basis.

\section{What are the determinants of migrant children's interactions with elderly parents?}

We now focus solely on migrant children, that is, those who have moved out of the province, and examine the factors that influence visits, cash remittances, and general support. Hypotheses derived from the altruism and vulnerability frameworks lead us to consider characteristics of both the adult child and their parents as relevant factors. Results of several logistic regression models are provided in Table 6. Reported here are regression coefficients and levels of significance. The smaller sample size in Cambodia has an impact on standard errors and therefore levels of significance. Thus, we consider sig- 
nificance to a $\mathrm{p}<0.10$ level to indicate a likely association. Moreover, as noted above, a very small proportion of Cambodian children give at least US\$25 per year to parents, hence coefficients predicting this outcome are unlikely to be statistically significant even if sizable. We therefore are more concerned with the direction of association for those coefficients that appear to be relatively large.

With respect to characteristics of migrant children, we observe several similar effects in the two countries. In both, female children appear to be more likely to interact with parents than male children. In Cambodia, daughters are more likely to visit regularly, provide household support, and give money, and in Thailand daughters are more likely to provide food or goods and give money. Second, higher education is associated with a greater tendency to interact with parents across all indicators, except for the provision of food or goods in Thailand. Finally, having two or more children of their own seems to reduce the tendency of adult children to give money to elderly parents in both countries.

Children's age has an impact on giving money and providing other support to elderly parents in both countries, although the age at which this type of exchange is most frequent differs. In both countries, children aged 16 to 24 are far less likely to provide these types of support than older children. In Cambodia, migrant children aged 40 and older are most likely to give money, while in Thailand children between 25 and 39 are most likely to do so. As mentioned earlier, rural migrants tend to be younger in Thailand than in Cambodia, while rural migrants in Cambodia may face greater difficulties in locating stable employment. Accordingly, adult children in Cambodia may require more time to accumulate the resources necessary to give money to elderly parents.

Turning to the characteristics of parents, the results are more mixed and only at times support the altruism and vulnerabilities frameworks. Children whose parents have worked in the past year and those whose parents have more children living outside the province are less likely to provide monetary and other support to parents and are less likely to visit. Elderly parents still involved in productive employment are likely to be in less vulnerable economic situations, all else being equal, than those who are not working, hence their need to rely upon migrant children should be less. From the migrant child's perspective, even when elderly parents face economic difficulties and need assistance, the presence of several other migrant children in the family should distribute the burden among a larger number of siblings. In other words, the altruistically motivated behavior of any one migrant child should be interpreted in light of the family collectivity, with the needs of potentially vulnerable parents being met through the combined efforts of resident, local, and migrant children.

Having a grandchild in the household without children nearby increases the probability of visits in Thailand. Having neither a child nor a grandchild nearby increases the probability of visits in Cambodia. In the case of elderly parents in Thailand, the absence of both children and grandchildren increases the probability that migrant children give food or goods as well as money. These results suggest that interactions between adult migrant children and their rural elderly parents are responsive, in part, to the absence of close kin in the parents' household. Where children and/or grandchildren are not present, 
elderly parents may be more vulnerable to loneliness, the labor demands of operating a household, insufficient sources of income, and other factors that threaten their sense of well-being.

We also find results that are either inconsistent between countries or, at least on first inspection, inconsistent with the altruism and vulnerabilities general frameworks. For instance, where both elderly parents are in the household, children in Cambodia are more rather than less likely to interact with parents across all indicators. In Thailand, the presence of both parents has little impact on the probability of a migrant child's interaction. The physical disability measure has practically no impact on these interactions in either country, and, if anything, decreases the odds of providing monetary support in Thailand, although this finding is not statistically significant. ${ }^{4}$

Although some of the results, such as those discussed in the preceding paragraph, appear contrary to expectations, the vulnerability perspective maintains that dependent states are the result of cumulative processes at the individual, familial, and community levels (Schröder-Butterfill and Marianti 2006a). It is therefore reasonable that the nature of vulnerability may derive from a multifaceted set of individual and contextual factors and the interaction of these factors, which are not fully captured in the present model. Accordingly, we further considered statistical interactions between the disabilities of adults and other factors indicative of need. We observed significant interaction effects between an elderly parent's number of disabilities and child/grandchild coresidence in predicting: a) visits in both countries, b) provision of general household support in Cambodia, and c) provision of food and goods in Thailand. These effects are displayed as predicted probabilities in Figures 1 to 4. Figures 1 and 2 show that in Cambodia, number of parental disabilities has a very strong positive impact on the probabilities of children visiting and providing general household support in those cases where the parent has neither a child living nearby nor a grandchild in the household. Although the number of such cases is small, our results indicate that general household support is almost guaranteed in these cases when the parent has multiple disabilities. We observe a statistically significant interaction of a slightly different nature in Thailand. Figures 3 and 4 show that disabilities increase the probabilities of visiting and provision of food and goods in cases where older adults live with grandchildren only.

The reason for the difference between countries with respect to interaction effects is difficult to surmise, and we acknowledge the small numbers of cases that are represented by the combination of multiple disabilities and specific residential arrangements. Still, the interaction effects that we report in Figures 1 to 4 are based only on those that are statistically significant. We conjecture that coresiding grandchildren are more likely to provide support to older adults in rural Cambodia than would be the case in rural Thailand, possibly because Cambodian children living elsewhere face greater economic demands that limit their ability to provide support to parents. Indeed, leaving a grandchild behind may be a strategic decision with the intended purpose of providing support, especially when older adults face physical disabilities that impair self-care and employment. In Thailand, where the general economic situation is better, parents coresiding with a grandchild may represent a circumstance in which the adult child migrated for the 
purpose of finding employment and supporting the members of the parents' household. Under this arrangement, both the migrant's own children and his or her elderly parents require support. Such households would require the migrant child's assistance especially in those cases where the elderly parent is incapacitated by physical disabilities.

\section{CONCLUSIONS}

Our comparative analysis indicates that although migration by adult children outside rural provinces is commonplace in Thailand and Cambodia, their elderly rural parents are not being abandoned. To the contrary, more than 80 percent of older adults in both countries were living with or next door to at least one grown child. Although having many adult children led to a higher probability of living near an adult child, substantial majorities of rural elderly with only one child were living either with this child nearby or within the same village. Moreover, from the perspective of adult children, those without siblings were much more likely to coreside with or live next door to their elderly parents than those with many siblings. Thus, our findings suggest that children's migration decisions are made with the needs of elderly parents in mind.

The organizing framework for our analysis of the determinants of children's interactions with older parents centered on notions of altruism and vulnerability. The altruistic perspective suggests that family members strive collectively to preserve the wellbeing of all members. Therefore, adult children of older adults who are more vulnerable are more likely to interact with and provide support to their parents. Still, the collective nature of altruism suggests that interactions with older parents depend additionally on the life circumstances of adult children. Those adult children who are in a better position to provide assistance will do so, though other family members will provide support as well. We find some support for this framework. Migrant children in Thailand and Cambodia are more likely to interact with parents who are not engaged in economic activity. We reasoned that parents' disability status would a have significant impact on interactions with adult migrant children since diminished capacity to conduct daily activities is a strong indicator of need. Our results on this matter were mixed. Parental disability appears to influence the provision of support by migrant children, but the disability variable works in concert with child/grandchild coresidence, and the nature of the association differs between countries. In Cambodia, disability increased visits and general household support to older parents who live without children or grandchildren. In Thailand, by comparison, disability increased visits and provision of food and goods to older parents living in households where grandchildren, but not children, were present.

Dissimilar determinants of parent-child interactions in different settings may result, in part, from distinctive economic structures. In our estimation, they also point to difficulties in identifying vulnerability across economic, demographic, and social settings. The vulnerability of older adults has several dimensions, including the physical, economic, social, and psychological (Schröder-Butterfill and Marianti 2006b). Our results suggest that these dimensions interact differently in different settings, leading to distinctive patterns of engagement between rural elderly and their adult children. In keeping 
with previous research, we recognize that although many rural elderly face circumstances that threaten their well-being, many others are embedded in social networks and economic circumstances that are protective and secure (ibid.). Further exploration of categories of dependence and their overlap in the lives of older adults could assist in modeling the determinants of intergenerational interaction between older parents in rural areas of developing societies and their children living elsewhere.

Identifying the determinants of children's support to older adults is further complicated by the network structure in which older adults are embedded. Most of the adult children in our study have siblings who may also provide various types of support to elderly parents. As past research has shown, the nature of intergenerational interactions with a particular child may be determined by reciprocal exchanges that involve a larger kinship network, and may further be influenced by socioeconomic conditions characteristic of a particular country or setting (Agree et al. 1999). Indeed, there are likely to be tradeoffs with respect to provision of support, types of support provided, and the timing of support vis-à-vis one's social and economic circumstances, and these tradeoffs may be difficult to model.

A number of weaknesses characterizing the current analysis should be recognized. First, the nine-year period between the Thailand and Cambodia surveys presents obstacles for making comparisons between countries. Nonetheless, we would not expect much change in the findings if we used a more recent Thai dataset. In fact, Thailand has continued its economic development and today would present an even greater contrast with Cambodia. Therefore, we might expect that dissimilarities found in the current study that are related to level of socioeconomic development would be even greater given more recent data from Thailand. Second, both surveys provide limited information on the migrant children of elderly parents and the nature of their migrations. Previous research suggests that the duration of migration and the distance separating migrants from their parents' households influence patterns of remittances and interactions. We do not have information in either survey about the specific location of migrant children, other than the fact that they live outside their parents' province, nor do we know how long they have lived in their current location. Third, given that previous research (e.g., Agree et al. 1999; Frankenberg et al. 2002) has shown that exchanges often flow in both directions over time, we recognize that our cross-sectional analysis of unidirectional measures of support do not fully capture the time-variant nature of intergenerational interaction. Fourth, our analysis does not take into account the broader kinship and support networks that also influence the living standards and needs for support of older adults in rural areas. Older adults may, for instance, live among a wide variety of kin in addition to, or in lieu of, a spouse, children, and grandchildren, and some may receive support from other sources, such as neighbors or other members of the community. Finally, although we begin to sketch the patterns and predictors of support provided to the rural elderly by their migrant children, we recognize that cross-sectional survey data collected solely from the perspective of elderly adults limit our ability to reach definitive conclusions about the causal nature of individual and contextual variables that influence migrant children's provision of support to elderly parents. 
In sum, a moderate degree of optimism is suggested by the patterns of living arrangements and provision of support to the rural elderly in Cambodia and Thailand. If economic and demographic changes taking place in these settings are altering the specific forms of interaction between adult children and their older parents - in particular, widening the physical distance between the elderly and some of their children-we find no evidence that this is leading to social abandonment. Many of our results are consistent with the notion, derived from an altruistic perspective, that migrant children are inclined to support their aged parents, especially when those parents possess characteristics indicative of vulnerability, for example the absence of involvement in productive employment.

While the interactions between adult migrant children in Thailand and Cambodia and their older parents appear to be responsive to parents' needs and motivated by filial piety, social structural and economic burdens may at times limit the degree of support. In Cambodia, in particular, the vulnerability of the elderly is in part the consequence of past decades of violence and upheaval that have reduced numbers of middle-aged children and increased the incidence of widowhood. By adopting a multigenerational perspective, researchers may consider whether, under certain circumstances, vulnerability endures across generations, so that younger adults are themselves made more vulnerable in their attempts to meet the needs of their elderly parents and kin.

\section{NOTES}

1 The Cambodian sample contains 23 older adults and the Thai sample 129 older adults with no children aged 16 and older. These individuals are omitted from all analyses.

2 The survey questions do not permit a perfect measure for the skipped-generation household arrangement. Our measure approximates the form, with the exception that households with a grandchild present and an adult child next door (but not in the same household) would not be counted. In practice, this should not be a problem since a child living next door is in close enough proximity to represent a living arrangement that includes both children and grandchildren. In contrast, while the surveys identify grandchildren living in the grandparents' household, they do not identify those living next door.

3 In keeping with other measures of coresidence, we consider living with an adult child to include situations in which the child lives next door, but living with spouse or grandchild refers to living in the same household. Also note that coresident persons other than spouse, children, or grandchildren are ignored in the tabulation.

4 The measure of disability utilizes four items for each survey, three of which are identical measures. In Cambodia, the fourth indicator is the ability to get up from bed unassisted, and in Thailand it is the ability to walk around the house unas- 
sisted. Given the different nature of these two activities, we conducted a sensitivity test using a measure created with the same three disability items in both countries. For Thailand, a negative association remains across all indicators of support, although the coefficient for giving money changes from significant to nonsignificant. For Cambodia, the association between number of disabilities and providing household support remains fairly substantial and becomes statistically significant, while associations with visiting and giving money remain small and non-significant. Generally, then, findings using three items are consistent with those using four items and do not change the overall nature of the results.

\section{REFERENCES}

Aboderin, Isabella. 2004. "Modernisation and ageing theory revisited: Current explanations of recent developing world and historical Western shifts in material family support for older people." Ageing \& Society 24: 29-50.

. 2005. "Conceptual levers for developing a better understanding of the motivational basis and societal shifts or patterns in old age family support." Working Paper No. WP205. Oxford Institute of Ageing Working Papers.

Agree, Emily, Ann E. Biddlecom, Thomas W. Valente, and Ming-Cheng Chang. 1999. "Social network measures of parent-child exchange: The applications in Taiwan and the Philippines." Connections 24(2): 59-75.

Albert, Stephen M. and Maria G. Cattell. 1994. "Family relationships of the elderly: Living arrangements." Pp. 85-107 in Old Age in Global Perspective: Cross-Cultural and Cross-National Views. G.K. Hall \& Co. and Maxwell Macmillan.

Apt, Nana A. 2000. "Rapid urbanization and living arrangement of older persons in Africa." Paper Presented at the United Nations Technical Meeting on Population Ageing and Living Arrangements of Older Persons: Critical Issues and Policy Responses, New York, 8-10 February.

Becker, Gary S. 1974. "A theory of social interactions." Journal of Political Economy 82(6): 1063-1093.

Bell, M., M. Blake, P. Boyle, O. Duke-Williams, and G. Hugo. 2002. "Cross-national comparison of internal migration: Issues and measures." Journal of the Royal Statistical Society 165(3): 435-464.

Bengtson, Vern L., Kyong-Dong Kim, George C. Myers, and Ki-Soo Eun (eds.). 2000. Aging in East and West: Families, States, and the Elderly. Springer Publishing Company. 
Bongaarts, John. 2002. "The end of the fertility transition in the developed world." Population and Development Review 28(3): 419-443.

Chan, Angelique. 1999. "The social and economic consequences of ageing in Asia." Southeast Asian Journal of Social Science 27(2): 1-8.

- 2005. "Formal and informal intergenerational support transfers in South-Eastern Asia." Report from United Nations Expert Group Meeting on Social and Economic Implications of Changing Population Age Structures. United Nations Secretariat. Mexico City, August.

Chandler, David P. 2000. A History of Cambodia. Boulder, CO: Westview Press.

Charasdamrong, Prasong. 1992. "The misery of those left behind." Bangkok Post, 10 May.

Chayovan, Napaporn and John Knodel. 1997. A Report on the Survey of the Welfare of the Elderly in Thailand. Institute of Population Studies, Chulalongkorn University.

Chi, Iris, Neena L. Chappell, and James Lubben (eds.). 2001. Elderly Chinese in Pacific Rim Countries: Social Support and Integration. Hong Kong University Press.

Curran, Sara R. 1996. "Intrahousehold exchange relations: Explanations for education and migration outcomes." Seattle Population Research Center Working Paper No. 96-5. University of Washington.

Diaz, Antonia and Cristina Echevarria. 2002. "Solidarity, transfers, and poverty." Review of Development Economics 6(3): 337-350.

Drèze, Jean. 1990. Widows in Rural India. London: Development Economics Research Programme.

Frankenberg, Elizabeth, Angelique Chan, and Mary Beth Ofstedal. 2002. "Stability and Change in Living Arrangements in Indonesia, Singapore, and Taiwan. 19931999." Population Studies 56: 201-213.

French, Howard W. 2006. "Rush for wealth in China's cities shatters the ancient assurance of care in old age." New York Times, 3 November.

Goldstein, Melvyn, Sidney Schuler, and James L. Ross. 1983. "Social and economic forces affecting intergenerational relations in extended families in a third world country: A cautionary tale from south Asia." Journal of Gerontology 38(6): 716724. 
Hermalin, Albert I. 2002a. "Aging in Asia: Facing the crossroads." In The Well-being of the Elderly in Asia: A Four-Country Comparative Study, edited by Albert I. Hermalin. Ann Arbor: University of Michigan Press. Pp. 1-24.

— (ed.). 2002b. The Well-Being of the Elderly in Asia: A Four-Country Comparative Study. The University of Michigan Press.

Huguet, Jerrold W., Aphichat Chamratrithirong, Nott Rama Rao and San Sy Than. 2000. "Results of the 1998 Population Census in Cambodia." Asia-Pacific Population Journal 15(3): 3-22.

Ikels, Charlotte and Cynthia Beall. 1993. "Settling accounts: The intergenerational contract in an age of reform." In Chinese Families in the Post-Mao Era, Deborah David and Stevan Harrell, eds. Berkeley: University of California Press.

Itzigsohn, Jose. 1995. "Migrant remittances, labor markets, and household strategies: A comparative analysis of low-income household strategies in the Caribbean Basin." Social Forces 74(2): 633-655.

Jampaklay, Aree. 2006. "How does leaving home affect marital timing? An event-history analysis of migration and marriage in Nang Rong, Thailand." Demography 43(4): $711-725$.

Katz, S., A.B. Ford, R.W. Moskowitz, B.A. Jackson, and M.W. Jaffee. 1963. "Studies of illness in the aged: The index of ADL, a standardized measure of biological and psychosocial function." Journal of the American Medical Association 185: 914919.

Kaufman, Daniel and David L. Lindauer 1986. "A model of income transfers for the urban poor." Journal of Development Economics 22: 337-350.

Knodel, John. Forthcoming. "Poverty and the impact of AIDS on older persons: Evidence from Cambodia and Thailand." Economic Development and Cultural Change.

Knodel, John and Napaporn Chayovan. 2001. "Sexual activity among older Thais: The influence of age, gender and health." Journal of Cross-Cultural Gerontology 16(2): 173-200.

Knodel, John, Napaporn Chayovan, Preeya Mithranon, Pattama Amornsirisomboon, and Supraporn Arunraksombat. 2005a. "Thailand's older population: Social and economic support as assessed in 2002." PSC Research Report 05-471. Ann Arbor, MI: Population Studies Center. 
Knodel, John and Nibhon Debavalya. 1997. "Living arrangements and support among the elderly in South-east Asia: An introduction." Asia-Pacific Population Journal 12(4): 5-16.

Knodel, John, Kiry Sovan Kim, Zachary Zimmer, and Sina Puch. 2005b. "Older persons in Cambodia: A profile from the 2004 Survey of Elderly." Phnom Penh, Cambodia: UNFPA and Royal University of Phnom Penh.

Knodel, John and Mary Beth Ofstedal. 2002. "Patterns and determinants of living arrangements." In The Well-Being of the Elderly in Asia: A Four-Country Comparative Study, edited by Albert I. Hermalin. University of Michigan Press. Pp. 143-184.

Knodel, John and Chanpen Saengtienchai. 2007. "Rural parents with urban children: Social and economic implications of migration for the rural elderly in Thailand." Population, Space and Place 12: 1-18.

Korinek, Kim and Barbara Entwisle. 2006. "Obligation and opportunity: The influence of gender, earnings, and household obligations on Thai migrants' remittance behavior," paper presented at the Population Association of America annual meeting, March.

Kreager, Philip. 2006. "Migration, social structure and old-age support networks: A comparison of three Indonesian communities." Ageing \& Society 26: 37-60.

Lee, Yean-Ju, William L. Parrish, and Robert J. Willis. 1994. "Sons, daughters, and intergenerational support in Taiwan." American Journal of Sociology 99(4): 1010-1041.

Liang, Jersey, Joan Bennett, Nancy Whitelaw, and Daisaku Maeda. 1991. "The structure of self-reported physical health among the aged in the United States and Japan." Medical Care 29(12): 1161-1180.

Lowenstein, Ariela and Svein Olav Daatland. 2006. "Filial norms and family support in comparative cross-national context: Evidence from the OASIS study." Ageing \& Society 26: 203-223.

Massey, Douglas S. and Lawrence C. Basem. 1992. "Determinants of savings, remittances, and spending patterns among U.S. migrants in four Mexican communities." Sociological Inquiry 62(2): 185-207.

Mason, Karen O. 1992. "Family change and support of the elderly in Asia: What do we know?" Asia-Pacific Population Journal 7(3): 13-32.

Melzer, David, Tzuo-Yun Lan, Brian D. M. Tom, Dorly J. H. Deeg, and Jack M. Guralnik. 2004. "Variation in thresholds for reporting mobility disability between na- 
tional population subgroups and studies." The Journals of Gerontology: Medical Sciences 59: 1295-1303.

Mills, Mary Beth. 1999. Thai Women in the Global Labor Force: Consuming Desires, Contested Selves. New Brunswick, NJ: Rutgers University Press.

Minicuci, N., M. Noale, S. M. F. Pluijm, et al. 2004. "Disability-free life expectancy: A cross-national comparison of six longitudinal studies on aging. The CLESA project." European Journal of Ageing 1(1): 37-44.

National Research Council. 2001. Preparing for an Aging World: The Case for CrossNational Research. Washington, DC: National Academy Press.

Ofstedal, Mary Beth, John Knodel, and Napaporn Chayovan. 1999. "Intergenerational support and gender: A comparison of four Asian countries." Southeast Asian Journal of Social Science 27: 21-42.

Osaki, Keiko. 2003. "Migrant Remittances in Thailand: Economic necessity or social norm?" Journal of Population Research 20(2): 203-223.

Petrova, P. 2003. "Does health status of parents affect transfers from their children? Evidence from Mexico." Working Paper, Department of Economics, Northeastern University. http://www.economics.neu.edu. Accessed on 15 May 2007.

Phillips, David R. 2000. "Ageing in the Asia-Pacific Region: Issues, Policies and Contexts." In Ageing in the Asia-Pacific Region: Issues, Policies and Future Trends, edited by David R. Phillips. New York, NY: Routledge. Pp. 1-34.

Sagaza, Haruo. 2004. "Population aging in the Asia-Oceania region." Geriatrics and Gerontology International 4: S34-S37.

Schröder-Butterfill, Elisabeth and Ruly Marianti. 2006a. "A framework for understanding old-age vulnerabilities." Ageing and Society 26: 9-35.

- 2006b. "Guest editorial: Understanding vulnerabilities in old age." Ageing \& Society 26: $3-8$.

Sengupta, Manisha and Emily M. Agree. 2002. "Gender and disability among older adults in north and south India: Differences associated with coresidence and marriage." Journal of Cross-Cultural Gerontology 17: 313-336.

Smith, Geoffrey C. 1998. "Residential separation and patterns of interaction between elderly parents and their adult children." Progress in Human Geography 22(3): 368384. 
Sobieszczyk, Teresa, John Knodel, and Napaporn Chayovan. 2003. "Gender and wellbeing among older people: Evidence from Thailand." Ageing and Society 23: 701735 .

Sokolovsky, Jay. 2001. "Living arrangements of older persons and family support in less developed countries." In Population Ageing and Living Arrangements of Older Persons: Critical Issues and Policy Responses, United Nations Population Bulletin, Special Issue Nos. 42/43. New York: United Nations.

Stark, Oded and David Bloom. 1985. "The new economics of labor migration." American Economic Review 75(2): 173-178.

Stark, Oded and R.E.B. Lucas. 1988. "Migration, remittances, and the family." Economic Development and Cultural Change 36: 465-481.

Su, Ya-Ping and Kenneth F. Ferraro. 1997. "Social relations and health assessments among older people: Do the effects of integration and social contributions vary cross-culturally?" Journal of Gerontology 52B(1): S27-S36.

United Nations. 1999. Towards a Society for All Ages. New York: United Nations.

—. 2002. Population Ageing and Development: Social, Health and Gender Issues. United Nations Population Fund. Population and Development Strategies.

- 2005a. Living Arrangements of Older Persons around the World. United Nations Population Division. New York: United Nations.

—. 2005b. World Population Prospects: The 2004 Revision. U.N.

United Nations Development Programme. 2007. Human Development Report 2006. http: //hdr.undp.org/ hdr2006/statistics. Accessed 27 March.

United Nations Population Division. 2007. World Population Prospects: The 2006 Revision and World Urbanization Prospects: The 2005 Revision. http: //esa.un.org/unpp. Accessed 27 March.

Vanwey, Leah K. 2004. "Altruistic and contractual remittances between male and female migrants and households in rural Thailand." Demography 41(4): 739-756.

Velkoff, Victoria. 2001. "Living arrangements and well-being of the older population: Future research directions." In Population Ageing and Living Arrangements of Older Persons: Critical Issues and Policy Responses, United Nations Population Bulletin, Special Issue Nos. 42/43. New York: United Nations. 
Watkins, John F. and Richard Ulack. 1991. "Migration and Regional Population Aging in the Philippines." Journal of Cross-cultural Gerontology 6(4): 383-411.

World Bank. 1994. Averting the Old Age Crisis: Policies to Protect the Old and Promote Growth. New York: Oxford University Press.

Wongsith, M. 1994. "Attitudes toward family values in rural Thailand." In Tradition and Change in the Asian Family, L. Cho and M. Yada (eds.). Honolulu: East West Center. Pp. 401-418.

Zimmer, Zachary and Napaporn Chayovan. 2000. "Health and social arrangements of aging parents in Thailand: Where are the children and what do they do?" Journal of Gerontology and Geriatric Medicine 1(2): 24-42.

Zimmer, Zachary and Sovan Kiry Kim. 2001. "Living arrangements and sociodemographic conditions of older adults in Cambodia." Journal of Cross-Cultural Gerontology 16(4): 353-381.

Zimmer, Zachary, John Knodel, Kiry Sovan Kim, and Sina Puch. 2006. "The impact of past conflicts and social disruption on the elderly in Cambodia." Population and Development Review 32(2): 333-360. 
Table 1 Residential proximity of children aged 16+ of rural parents aged 60+, Cambodia 2004 and Thailand $1995^{\mathrm{a}}$ (percent)

\begin{tabular}{|c|c|c|c|c|c|c|}
\hline & $\mathrm{N}^{\mathrm{b}}$ & Nearby $^{\mathrm{c}}$ & $\begin{array}{l}\text { In } \\
\text { village }\end{array}$ & $\begin{array}{l}\text { Outside } \\
\text { village but } \\
\text { in province }\end{array}$ & $\begin{array}{l}\text { Outside } \\
\text { province }\end{array}$ & Total \\
\hline \multicolumn{7}{|c|}{$\begin{array}{l}\text { Percent of older adults } \\
\text { with } 1+\text { adult children living... }\end{array}$} \\
\hline Cambodia & 777 & 82.7 & 67.7 & 47.4 & 49.1 & n.a. \\
\hline Thailand & 3202 & 82.8 & 86.9 & 61.1 & 64.5 & n.a. \\
\hline \multicolumn{7}{|l|}{ Where nearest child lives } \\
\hline Cambodia & 777 & 82.7 & 12.0 & 3.2 & 2.0 & 100.0 \\
\hline Thailand & 3202 & 82.8 & 9.3 & 4.5 & 3.4 & 100.0 \\
\hline \multicolumn{7}{|l|}{$\begin{array}{l}\text { Where nearest adult child } \\
\text { lives, given that at least one } \\
\text { adult child lives... } \\
\text { Cambodia }\end{array}$} \\
\hline Outside village & 553 & 80.7 & 11.9 & 4.5 & 2.8 & 100.0 \\
\hline Outside village/in province & 364 & 81.1 & 12.1 & 6.8 & 0.0 & 100.0 \\
\hline Outside province & 380 & 78.9 & 11.7 & 5.3 & 4.1 & 100.0 \\
\hline \multicolumn{7}{|l|}{ Thailand } \\
\hline Outside village & 2762 & 81.1 & 9.8 & 5.2 & 3.9 & 100.0 \\
\hline Outside village/in province & 1836 & 83.0 & 9.7 & 7.3 & 0.0 & 100.0 \\
\hline Outside province & 2128 & 78.4 & 10.3 & 6.1 & 5.3 & 100.0 \\
\hline
\end{tabular}

\section{Where nearest child lives by} number of children aged $16+$ Cambodia

$\begin{array}{lrrrrrr}1 & 64 & 76.5 & 4.9 & 2.5 & 16.0 & 100.0 \\ 2 & 74 & 72.3 & 18.1 & 7.4 & 2.1 & 100.0 \\ 3 & 82 & 71.7 & 18.2 & 9.1 & 1.0 & 100.0 \\ 4 & 124 & 84.1 & 11.6 & 3.0 & 1.2 & 100.0 \\ 5+ & 433 & 86.8 & 11.4 & 1.5 & 0.3 & 100.0\end{array}$

Thailand

\begin{tabular}{lrrrrrr}
1 & 150 & 69.2 & 7.0 & 7.0 & 16.8 & 100.0 \\
2 & 237 & 66.1 & 16.7 & 8.4 & 8.8 & 100.0 \\
3 & 346 & 82.5 & 7.0 & 5.6 & 5.0 & 100.0 \\
4 & 433 & 77.8 & 13.2 & 5.1 & 4.0 & 100.0 \\
$5+$ & 2036 & 86.5 & 8.2 & 3.7 & 1.6 & 100.0 \\
\hline
\end{tabular}

${ }^{\mathrm{a}}$ The Cambodian sample contains an additional 23 individuals, and the Thai sample contains an additional 129 individuals without any children aged 16+. These individuals are omitted. $\quad{ }^{b} \mathrm{~N}$ 's are unweighted; results are weighted. $\quad{ }^{\mathrm{c}}$ In same household or next door. 
Table 2 Percent distribution of living arrangements of rural parents aged $60+$ with migrant children aged 16+Cambodia 2004 and Thailand $1995^{\mathrm{a}}$

\begin{tabular}{lcc}
\hline & $\begin{array}{c}\text { Cambodia } \\
(\mathrm{N}=756)\end{array}$ & $\begin{array}{c}\text { Thailand } \\
(\mathrm{N}=5520)\end{array}$ \\
\hline Lives with spouse and with & & \\
1+ children and 1+ grandchildren & 24.8 & 22.3 \\
1+ children & 19.4 & 25.3 \\
1+ grandchildren & 7.8 & 2.5 \\
Neither children nor grandchildren & 9.2 & 17.2 \\
Does not live with spouse and lives with & & \\
1+ children and 1+ grandchildren & 25.9 & 15.4 \\
1+ children & 5.5 & 10.4 \\
1+ grandchildren & 5.1 & 1.2 \\
Neither children nor grandchildren & 2.2 & 5.9 \\
Total & 100.0 & 100.0 \\
\hline${ }^{a}$ A migrant child is one living outside the province in which the parents reside.
\end{tabular}

${ }^{a} \mathrm{~A}$ migrant child is one living outside the province in which the parents reside. 
Table 3 Residential location of children aged 16+ of rural parents aged $60+$, by children's characteristics, Cambodia 2004 and Thailand 1995 (percent)

\begin{tabular}{|c|c|c|c|c|c|c|}
\hline & $(\mathrm{N})^{\mathrm{a}}$ & $\begin{array}{l}\text { Nearby }^{b} \\
(\mathrm{~N}=1112)\end{array}$ & $\begin{array}{l}\text { Village } \\
(\mathrm{N}=1214)\end{array}$ & $\begin{array}{l}\text { Province } \\
(\mathrm{N}=669)\end{array}$ & $\begin{array}{l}\text { Outside } \\
\text { province } \\
(\mathrm{N}=756) \\
\end{array}$ & $\begin{array}{l}\text { Total } \\
(\mathrm{N}=3751)\end{array}$ \\
\hline $\begin{array}{l}\text { Cambodia } \\
\text { Total }\end{array}$ & $(3,751)$ & 28.7 & 33.1 & 17.9 & 20.4 & 100.0 \\
\hline $\begin{array}{l}\text { Total number of } \\
\text { children } 16+\text { in sibshi } \\
\quad 1 \\
2 \\
3 \\
4 \\
5+ \\
\chi^{2}=144.4 ; \mathrm{p}<0.00\end{array}$ & $\begin{array}{r}(64) \\
(148) \\
(244) \\
(489) \\
(2,806)\end{array}$ & $\begin{array}{l}76.5 \\
43.1 \\
30.5 \\
32.8 \\
26.2\end{array}$ & $\begin{array}{r}4.9 \\
28.7 \\
34.6 \\
35.1 \\
33.4\end{array}$ & $\begin{array}{r}2.5 \\
10.7 \\
16.9 \\
22.2 \\
18.6\end{array}$ & $\begin{array}{l}16.0 \\
17.6 \\
18.0 \\
15.1 \\
21.7\end{array}$ & $\begin{array}{l}100.0 \\
100.0 \\
100.0 \\
100.0 \\
100.0\end{array}$ \\
\hline $\begin{array}{l}\text { Sex } \\
\quad \text { Son } \\
\text { Daughter } \\
\chi^{2}=280.4 ; p<0.00\end{array}$ & $\begin{array}{l}(1,729) \\
(2,022)\end{array}$ & $\begin{array}{l}18.5 \\
37.6\end{array}$ & $\begin{array}{l}33.9 \\
32.3\end{array}$ & $\begin{array}{l}24.1 \\
12.4\end{array}$ & $\begin{array}{l}23.5 \\
17.6\end{array}$ & $\begin{array}{l}100.0 \\
100.0\end{array}$ \\
\hline $\begin{array}{l}\text { Age } \\
\qquad \begin{array}{l}16-24 \\
25-29 \\
30-34 \\
35-39 \\
40-44 \\
45-49 \\
50+ \\
\chi^{2}=613.9 ; \mathrm{p}<0.00\end{array}\end{array}$ & $\begin{array}{l}(547) \\
(449) \\
(619) \\
(756) \\
(638) \\
(393) \\
(349)\end{array}$ & $\begin{array}{l}64.5 \\
32.7 \\
22.1 \\
21.4 \\
20.2 \\
18.5 \\
23.2\end{array}$ & $\begin{array}{l}16.0 \\
31.4 \\
32.8 \\
36.4 \\
42.5 \\
34.2 \\
36.3\end{array}$ & $\begin{array}{r}7.0 \\
16.8 \\
18.4 \\
19.2 \\
18.9 \\
25.5 \\
21.7\end{array}$ & $\begin{array}{l}12.5 \\
19.1 \\
26.8 \\
23.1 \\
18.4 \\
21.8 \\
18.9\end{array}$ & $\begin{array}{l}100.0 \\
100.0 \\
100.0 \\
100.0 \\
100.0 \\
100.0 \\
100.0\end{array}$ \\
\hline $\begin{array}{l}\text { Education }^{c} \\
\text { None } \\
\text { Incomplete primary } \\
\text { or pagoda } \\
\text { Complete primary } \\
\text { Secondary } \\
\text { Beyond } \\
\gamma^{2}=1976 \cdot 0<00\end{array}$ & $\begin{array}{r}(630) \\
(1,543) \\
(515) \\
(914) \\
(64)\end{array}$ & $\begin{array}{l}31.4 \\
26.5 \\
28.9 \\
32.3 \\
29.7\end{array}$ & $\begin{array}{r}38.6 \\
\\
37.8 \\
32.0 \\
25.0 \\
7.9\end{array}$ & $\begin{array}{l}15.8 \\
17.6 \\
21.1 \\
17.7 \\
12.9\end{array}$ & $\begin{array}{l}14.2 \\
\\
18.2 \\
18.0 \\
25.0 \\
49.5\end{array}$ & $\begin{array}{l}100.0 \\
100.0 \\
100.0 \\
100.0 \\
100.0\end{array}$ \\
\hline $\begin{array}{l}\text { Married } \\
\quad \text { Not married } \\
\text { Married } \\
\chi^{2}=1594.0 ; \mathrm{p}<0.00\end{array}$ & $\begin{array}{r}(852) \\
(2,899)\end{array}$ & $\begin{array}{l}75.7 \\
15.3\end{array}$ & $\begin{array}{r}7.8 \\
40.2\end{array}$ & $\begin{array}{r}3.5 \\
21.9\end{array}$ & $\begin{array}{l}13.0 \\
22.5\end{array}$ & $\begin{array}{l}100.0 \\
100.0\end{array}$ \\
\hline $\begin{array}{l}\text { Number of children } \\
\text { None } \\
\text { One } \\
\text { Two }+ \\
\chi^{2}=200.3 ; p<0.00\end{array}$ & $\begin{array}{r}(781) \\
(496) \\
(2,474)\end{array}$ & $\begin{array}{l}68.5 \\
29.1 \\
16.1\end{array}$ & $\begin{array}{r}7.9 \\
33.3 \\
40.9\end{array}$ & $\begin{array}{r}5.7 \\
15.4 \\
22.2\end{array}$ & $\begin{array}{l}17.8 \\
22.2 \\
20.8\end{array}$ & $\begin{array}{l}100.0 \\
100.0 \\
100.0\end{array}$ \\
\hline
\end{tabular}


Table 3 Continued

\begin{tabular}{|c|c|c|c|c|c|c|}
\hline & $(\mathrm{N})^{\mathrm{a}}$ & $\begin{array}{l}\text { Nearby }^{\mathrm{d}} \\
(\mathrm{N}=4986)\end{array}$ & $\begin{array}{l}\text { Village } \\
(\mathrm{N}=3414)\end{array}$ & $\begin{array}{l}\text { Province } \\
(\mathrm{N}=3597)\end{array}$ & $\begin{array}{l}\text { Outside } \\
\text { province } \\
(\mathrm{N}=5520) \\
\end{array}$ & $\begin{array}{l}\text { Total } \\
(\mathrm{N}=17,517)\end{array}$ \\
\hline $\begin{array}{c}\text { Thailand } \\
\text { Total }\end{array}$ & $(17,517)$ & 29.4 & 19.8 & 21.6 & 29.2 & 100.0 \\
\hline $\begin{array}{l}\text { Total number of } \\
\text { children } 16+\text { in sibship } \\
1 \\
2 \\
3 \\
4 \\
5+ \\
\chi^{2}=310.8 ; \mathrm{p}<0.00\end{array}$ & $\begin{array}{r}(150) \\
(474) \\
(1038) \\
(1732) \\
(14,123)\end{array}$ & $\begin{array}{l}69.2 \\
42.5 \\
43.3 \\
34.3 \\
27.2\end{array}$ & $\begin{array}{r}7.0 \\
15.4 \\
16.3 \\
17.2 \\
20.6\end{array}$ & $\begin{array}{r}7.0 \\
18.6 \\
18.0 \\
20.0 \\
22.2\end{array}$ & $\begin{array}{l}16.8 \\
23.6 \\
22.4 \\
28.5 \\
30.0\end{array}$ & $\begin{array}{l}100.0 \\
100.0 \\
100.0 \\
100.0 \\
100.0\end{array}$ \\
\hline $\begin{array}{l}\text { Sex } \\
\quad \text { Son } \\
\text { Daughter } \\
\chi^{2}=223.8 ; p<0.00\end{array}$ & $\begin{array}{l}(8639) \\
(8878)\end{array}$ & $\begin{array}{l}24.9 \\
33.7\end{array}$ & $\begin{array}{l}19.5 \\
20.1\end{array}$ & $\begin{array}{l}24.2 \\
19.1\end{array}$ & $\begin{array}{l}31.3 \\
27.1\end{array}$ & $\begin{array}{l}100.0 \\
100.0\end{array}$ \\
\hline $\begin{array}{l}\text { Age }^{\mathrm{e}} \\
16-24 \\
25-29 \\
30-34 \\
35-39 \\
40-44 \\
45-49 \\
50+ \\
\chi^{2}=1021.2 ; \mathrm{p}<0.00\end{array}$ & $\begin{array}{l}(1582) \\
(2388) \\
(3294) \\
(3617) \\
(2866) \\
(1687) \\
(1634)\end{array}$ & $\begin{array}{l}43.7 \\
35.3 \\
30.4 \\
26.6 \\
24.9 \\
23.7 \\
24.7\end{array}$ & $\begin{array}{r}7.6 \\
13.0 \\
18.6 \\
23.3 \\
24.1 \\
24.8 \\
26.2\end{array}$ & $\begin{array}{l}10.6 \\
15.5 \\
21.0 \\
23.5 \\
26.1 \\
26.0 \\
29.7\end{array}$ & $\begin{array}{l}38.1 \\
36.1 \\
30.0 \\
26.6 \\
25.0 \\
25.5 \\
19.4\end{array}$ & $\begin{array}{l}100.0 \\
100.0 \\
100.0 \\
100.0 \\
100.0 \\
100.0 \\
100.0\end{array}$ \\
\hline $\begin{array}{l}\text { Education }^{\mathrm{f}} \\
\text { None } \\
\text { Incomplete primary } \\
\text { or pagoda } \\
\text { Complete primary } \\
\text { Secondary } \\
\text { Beyond } \\
\chi^{2}=844.1 ; \mathrm{p}<0.00\end{array}$ & $\begin{array}{r}(725) \\
(535) \\
(12,936) \\
(2128) \\
(1027)\end{array}$ & $\begin{array}{l}32.0 \\
35.5 \\
30.6 \\
26.0 \\
19.0\end{array}$ & $\begin{array}{r}24.0 \\
20.8 \\
22.4 \\
9.7 \\
6.5\end{array}$ & $\begin{array}{l}19.3 \\
21.5 \\
21.7 \\
20.0 \\
23.9\end{array}$ & $\begin{array}{l}24.7 \\
22.2 \\
25.2 \\
44.3 \\
50.6\end{array}$ & $\begin{array}{l}100.0 \\
100.0 \\
100.0 \\
100.0 \\
100.0\end{array}$ \\
\hline $\begin{array}{l}\text { Married }^{\mathrm{g}} \\
\quad \text { Not married } \\
\text { Married } \\
\chi^{2}=1510.6 ; \mathrm{p}<0.00\end{array}$ & $\begin{array}{r}3427 \\
14,083\end{array}$ & $\begin{array}{l}49.2 \\
24.5\end{array}$ & $\begin{array}{r}6.8 \\
23.1\end{array}$ & $\begin{array}{r}9.0 \\
24.8\end{array}$ & $\begin{array}{l}35.1 \\
27.7\end{array}$ & $\begin{array}{l}100.0 \\
100.0\end{array}$ \\
\hline $\begin{array}{l}\text { Number of children } \\
\text { None } \\
\text { One } \\
\text { Two }+ \\
\chi^{2}=1654.7 ; p<0.00\end{array}$ & $\begin{array}{r}3825 \\
3316 \\
10,294\end{array}$ & $\begin{array}{l}43.2 \\
29.9 \\
23.9\end{array}$ & $\begin{array}{r}5.8 \\
17.3 \\
26.3\end{array}$ & $\begin{array}{l}12.0 \\
20.7 \\
25.7\end{array}$ & $\begin{array}{l}39.0 \\
32.2 \\
24.1\end{array}$ & $\begin{array}{l}100.0 \\
100.0 \\
100.0\end{array}$ \\
\hline
\end{tabular}


Table 3 Continued ${ }^{a}$ N's are unweighted; results are weighted. ${ }^{\mathrm{b}}$ Includes 993 living in same household
plus 119 living next door. ${ }^{\mathrm{c}}$ Excludes 85 cases where parent does not know the educa-
tion of their child. ${ }_{\mathrm{d}}^{\mathrm{d}}$ Includes 3063 living in same household plus 1923 living next door.
${ }^{\mathrm{e}}$ Excludes 449 cases where parent does not know the age of their child. ${ }^{\mathrm{f}}$ Excludes 166
cases where parent does not know the education of their child. ${ }_{\mathrm{g}}^{\mathrm{g}}$ Excludes 7 cases
where parent does not know the marital status of their child. ${ }^{\mathrm{h}}$ Excludes 82 cases where
parent does not know how many children their child has. 
Table 4 Percent of children aged 16+ engaging in selected forms of interaction with rural parents aged 60+, by child's residential location, Cambodia 2004 and Thailand 1995

\begin{tabular}{|c|c|c|c|c|c|}
\hline $\begin{array}{l}\text { Where adult } \\
\text { child lives }\end{array}$ & $(\mathrm{N})^{\mathrm{a}}$ & $\begin{array}{r}\text { Visits at } \\
\text { least } \\
\text { monthly }\end{array}$ & $\begin{array}{c}\text { Gives } \\
\text { money }^{\mathrm{b}}\end{array}$ & $\begin{array}{r}\text { Provides } \\
\text { general } \\
\text { household } \\
\text { support }^{\mathrm{c}} \\
\end{array}$ & $\begin{array}{r}\text { Provides food } \\
\text { or goods } \\
\text { at least } \\
\text { monthly } \\
\end{array}$ \\
\hline \multicolumn{6}{|l|}{ Cambodia } \\
\hline Nearby $^{\mathrm{e}}$ & (1112) & na & 10.0 & 73.9 & na \\
\hline Village & (1214) & 97.3 & 2.1 & 45.3 & na \\
\hline Province & (669) & 59.2 & 1.7 & 35.4 & na \\
\hline Outside province & (756) & 23.6 & 10.6 & 45.0 & na \\
\hline \multirow{2}{*}{ Chi-square } & & $1,591.1$ & 155.4 & 429.6 & na \\
\hline & & $\mathrm{p}<0.00$ & $\mathrm{p}<0.00$ & $\mathrm{p}<0.00$ & \\
\hline \multicolumn{6}{|l|}{ Thailand } \\
\hline Nearby ${ }^{f}$ & (4932) & na & 33.5 & na & $\mathrm{na}^{\mathrm{h}}$ \\
\hline Village & $(3385-3411)^{\mathrm{g}}$ & 91.9 & 18.0 & na & 46.7 \\
\hline Province & $(3582-3596)^{\mathrm{g}}$ & 63.9 & 26.2 & na & 30.9 \\
\hline Outside province & $(5498-5507)^{\mathrm{g}}$ & 18.9 & 45.1 & na & 11.3 \\
\hline \multirow{2}{*}{\multicolumn{2}{|c|}{ Chi-square }} & 5258.2 & 879.6 & na & 1523.9 \\
\hline & & $\mathrm{p}<0.00$ & $\mathrm{p}<0.00$ & & $\mathrm{p}<0.00$ \\
\hline
\end{tabular}

na $=$ not applicable.

${ }^{a}$ N's are unweighted; results are weighted. ${ }^{b}$ At least US $\$ 25$ annually. $\quad{ }^{c}$ Not asked in Thailand. ${ }^{\mathrm{d}}$ Not asked in Cambodia. ${ }^{\mathrm{e}}$ Includes 993 living in same household plus 119 living next door. ${ }^{\mathrm{f}}$ Includes 3063 living in same household plus 1923 living next door. ${ }^{\mathrm{g}}$ Some missing responses exist. Range represents maximum and minimum number of cases across response. ${ }^{\mathrm{h}}$ Not calculated since questions not asked about coresident children. 
Table 5 Percent of children aged 16+ who live outside province engaging in selected forms of interactions with rural parents aged $60+$, by whether they visit, provide money, or provide other support, Cambodia 2004 and Thailand $1995^{\circ}$

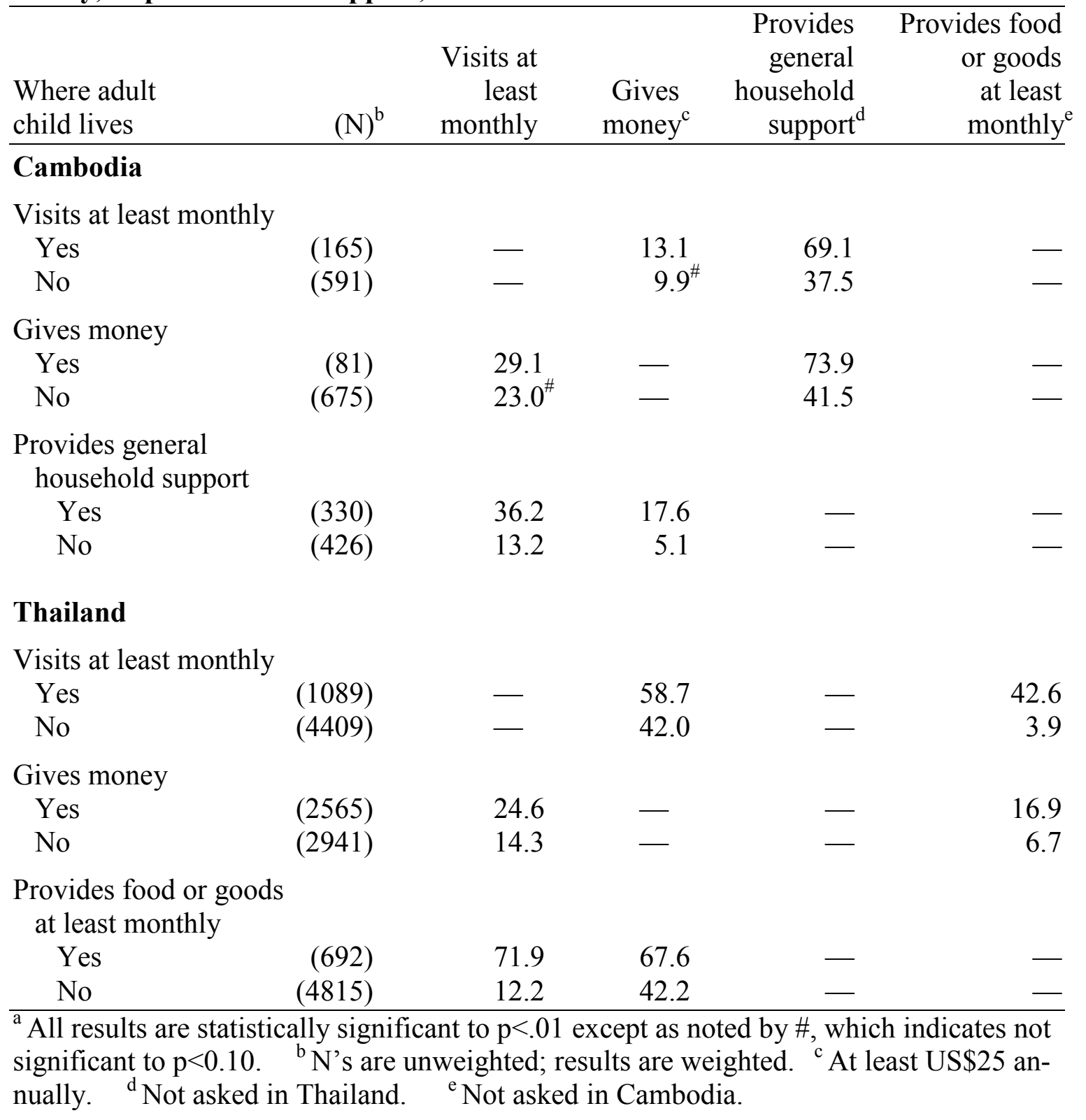


Table 6 Logistic regression coefficients for visiting rural parents aged $60+$ at least monthly, giving money, providing general household support, or providing food or goods at least monthly, among children aged 16+ who live outside province, Cambodia 2004 and Thailand 1995

\begin{tabular}{|c|c|c|c|c|c|c|}
\hline & \multicolumn{3}{|c|}{ Cambodia } & \multicolumn{3}{|c|}{ Thailand } \\
\hline & $\begin{array}{l}\text { Visits } \\
\text { at least } \\
\text { monthly }\end{array}$ & $\begin{array}{l}\text { Gives } \\
\text { money }^{\mathrm{a}}\end{array}$ & $\begin{array}{l}\text { Provides } \\
\text { general } \\
\text { household } \\
\text { support }\end{array}$ & $\begin{array}{l}\text { Visits } \\
\text { at least } \\
\text { monthly }\end{array}$ & $\begin{array}{l}\text { Gives } \\
\text { money }^{\mathrm{a}}\end{array}$ & $\begin{array}{l}\text { Provides } \\
\text { food or } \\
\text { goods at } \\
\text { least monthly }\end{array}$ \\
\hline \multicolumn{7}{|c|}{ Characteristics of migrant child } \\
\hline Female & $0.470^{*}$ & 0.282 & $0.652 * *$ & 0.059 & $0.311 * *$ & $0.411 * *$ \\
\hline \multicolumn{7}{|l|}{ Age (vs. 16-24) ${ }^{\mathrm{b}}$} \\
\hline $25-29$ & -0.302 & 1.113 & 0.407 & -0.155 & $0.352 *$ & 0.368 \\
\hline $30-34$ & 0.153 & 0.984 & 0.438 & -0.141 & $0.380 * *$ & $0.494 *$ \\
\hline $35-39$ & -0.504 & $1.329^{\wedge}$ & 0.563 & -0.038 & $0.489 * *$ & $0.428^{\wedge}$ \\
\hline $40-44$ & -0.117 & $1.780^{*}$ & 0.501 & -0.310 & 0.229 & 0.246 \\
\hline $45-49$ & -0.539 & $1.723 *$ & 0.008 & -0.074 & 0.150 & 0.049 \\
\hline $50+$ & -0.629 & 0.930 & 0.153 & 0.053 & 0.215 & 0.394 \\
\hline \multicolumn{7}{|l|}{ Education (vs. none) ${ }^{\mathrm{c}}$} \\
\hline $\begin{array}{l}\text { Incomplete primary } \\
\text { (vs. none) }\end{array}$ & -0.059 & $-0.716^{\wedge}$ & -0.160 & $-0.925^{\wedge}$ & 0.551 & -0.604 \\
\hline Complete primary & -0.020 & -0.665 & 0.536 & 0.076 & $1.081 * *$ & 0.116 \\
\hline Secondary & $0.985 * *$ & 0.143 & $1.007 * *$ & $0.708 *$ & $1.553 * *$ & 0.596 \\
\hline More than secondary & $2.496 * *$ & $1.161^{\wedge}$ & $1.057^{\wedge}$ & $0.967 * *$ & $1.582 * *$ & 0.583 \\
\hline Is married $^{\mathrm{d}}$ & -0.272 & 0.704 & 0.353 & 0.103 & -0.042 & -0.152 \\
\hline \multicolumn{7}{|l|}{$\begin{array}{l}\text { Number of own } \\
\text { children (vs. } 0)^{b}\end{array}$} \\
\hline 1 & 0.350 & 0.622 & -0.026 & 0.002 & -0.190 & 0.149 \\
\hline 2 & 0.016 & -0.592 & -0.357 & -0.073 & $-0.469 * *$ & 0.030 \\
\hline \multicolumn{7}{|c|}{ Characteristics of parent } \\
\hline $65-69$ & $-0.455^{\wedge}$ & 0.244 & 0.160 & 0.030 & 0.009 & 0.152 \\
\hline $70-74$ & $-0.737 *$ & 0.692 & 0.372 & 0.117 & $-0.333 * *$ & -0.090 \\
\hline $75+$ & -0.268 & 0.636 & $0.665^{*}$ & 0.001 & -0.008 & 0.124 \\
\hline Female & 0.182 & $1.234 * *$ & $0.724 * *$ & 0.059 & $0.195^{*}$ & 0.520 \\
\hline Spouse present & $0.478^{\wedge}$ & 0.343 & $0.415^{\wedge}$ & $0.415^{\wedge}$ & -0.037 & -0.022 \\
\hline Any education & -0.216 & 0.408 & $0.665 * *$ & 0.050 & $0.487 * *$ & $0.239^{\wedge}$ \\
\hline Occupation agriculture & 0.183 & 0.513 & $-0.992 *$ & $-0.499 * *$ & 0.001 & $-0.696 * *$ \\
\hline Worked in past year & $-1.209 * *$ & 0.296 & $-0.380 *$ & $-0.178^{\wedge}$ & $-0.274 * *$ & $-0.288^{*}$ \\
\hline Number of disabilities & 0.087 & 0.037 & 0.147 & -0.007 & $-0.200 * *$ & -0.078 \\
\hline $\begin{array}{l}\text { Number children living } \\
\text { outside province }\end{array}$ & $0.237 * *$ & -0.113 & $0.086^{\wedge}$ & $-0.122 * *$ & $-0.047 * *$ & $-0.095 * *$ \\
\hline
\end{tabular}




\begin{tabular}{|c|c|c|c|c|c|}
\hline \multicolumn{3}{|c|}{ Cambodia } & \multicolumn{3}{|c|}{ Thailand } \\
\hline $\begin{array}{l}\text { Visits } \\
\text { at least } \\
\text { monthly }\end{array}$ & $\begin{array}{l}\text { Gives } \\
\text { money }^{\mathrm{a}}\end{array}$ & $\begin{array}{l}\text { Provides } \\
\text { general } \\
\text { household } \\
\text { support }\end{array}$ & $\begin{array}{l}\text { Visits } \\
\text { at least } \\
\text { monthly }\end{array}$ & $\begin{array}{l}\text { Gives } \\
\text { money }^{\mathrm{a}}\end{array}$ & $\begin{array}{l}\text { Provides } \\
\text { food or } \\
\text { goods at } \\
\text { least monthly }\end{array}$ \\
\hline
\end{tabular}

Child/grandchild coresidence

(vs. children nearby) ${ }^{\mathrm{e}}$

Children nearby and grandchildren in

$\begin{array}{lllll}0.205 & -0.027 & 0.206 & 0.103 & -0.044\end{array}$

Grandchildren in household without children nearby

$\begin{array}{llllll}-0.239 & -0.053 & 0.371 & 0.517 * * & 0.127 & 0.114\end{array}$

Neither children nearby nor grandchildren in household

$\begin{array}{rrrrrr}0.673^{\wedge} & -0.369 & -0.104 & 0.125 & -0.215^{*} & 0.340^{*} \\ -1.921 & -4.982 & -2.797 & -1.056 & -1.576 & -2.164 \\ -337.2 & -230.2 & -465.7 & -2514.5 & -3542.9 & -1832.7\end{array}$

Constant 120.7 62.1 85.8 $152.8 \quad 269.9$ 122.6 $* * \mathrm{p}<0.01 * \mathrm{p}<0.05 \wedge \mathrm{p}<0.10$

a At least US\$25 annually. $\quad{ }^{\mathrm{b}}$ Category for "parent does not know" included in the equation but not reported for Thailand. $\quad$ c Category for "parent does not know" included in the equation but not reported for either Cambodia or Thailand. ${ }^{\mathrm{d}}$ Excludes 7 cases where parent does not know the marital status of child. $\quad{ }^{\mathrm{e}}$ Nearby means children living in the household or next door. 

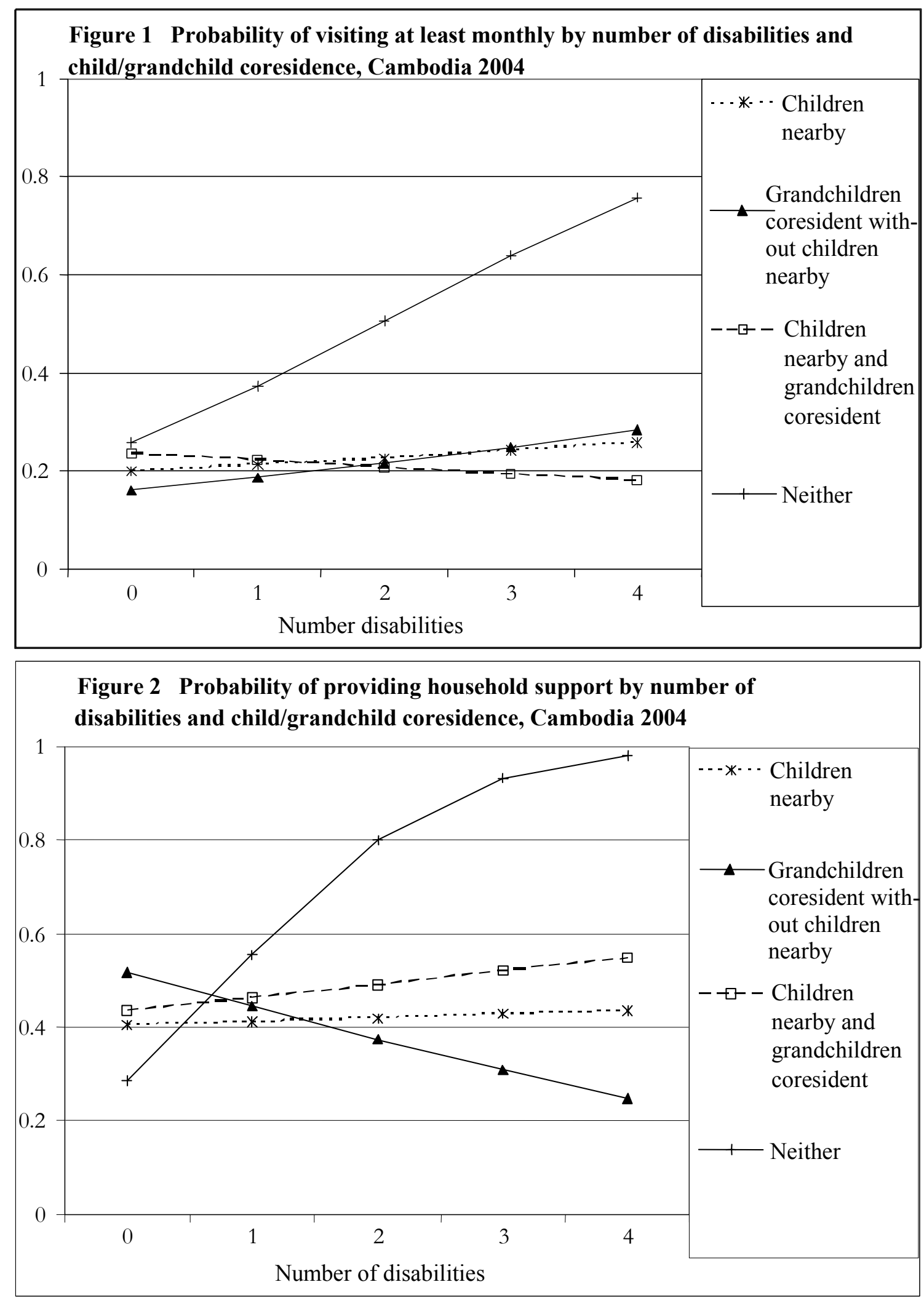


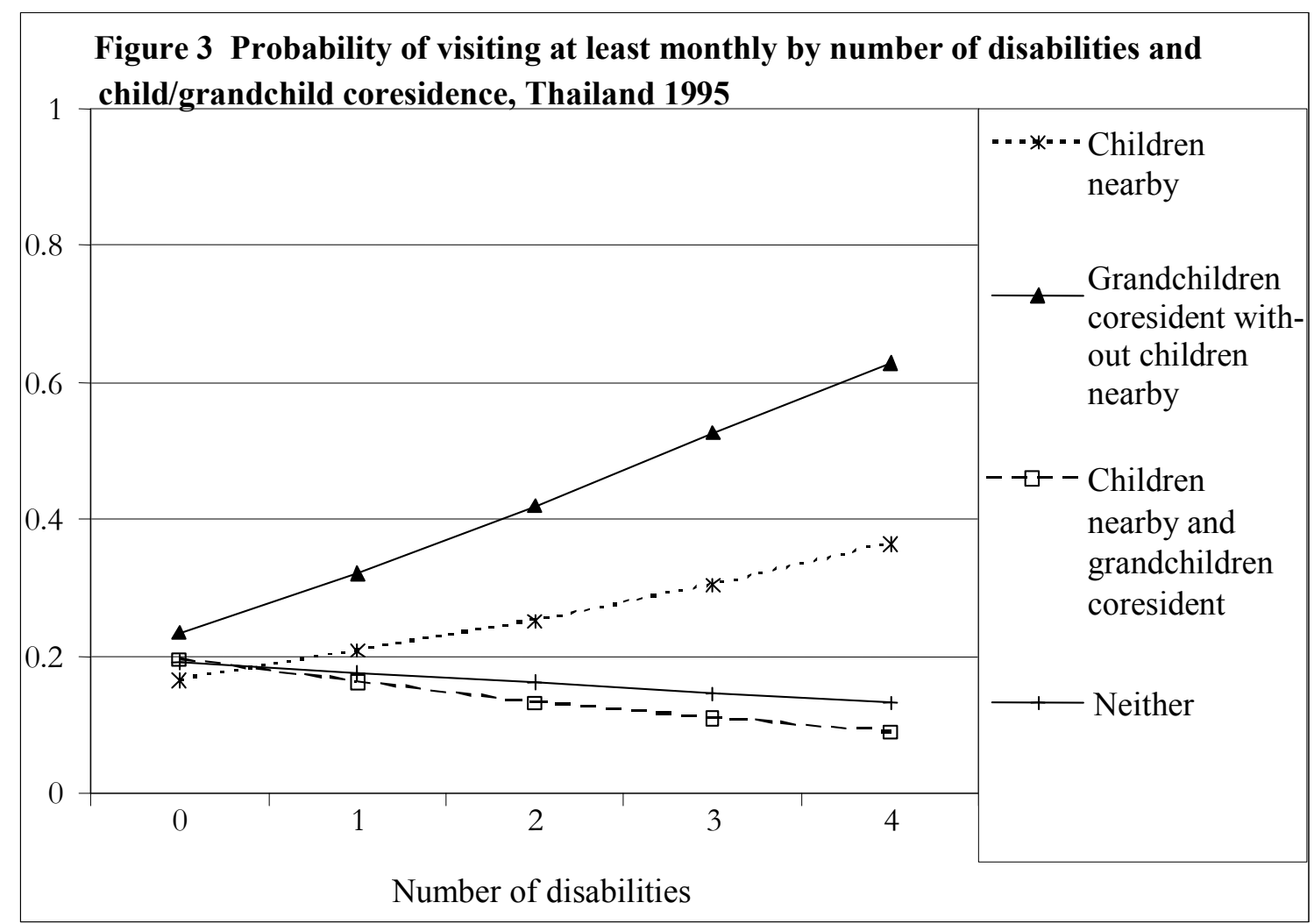

Figure 4 Probability of providing goods or food regularly by number of
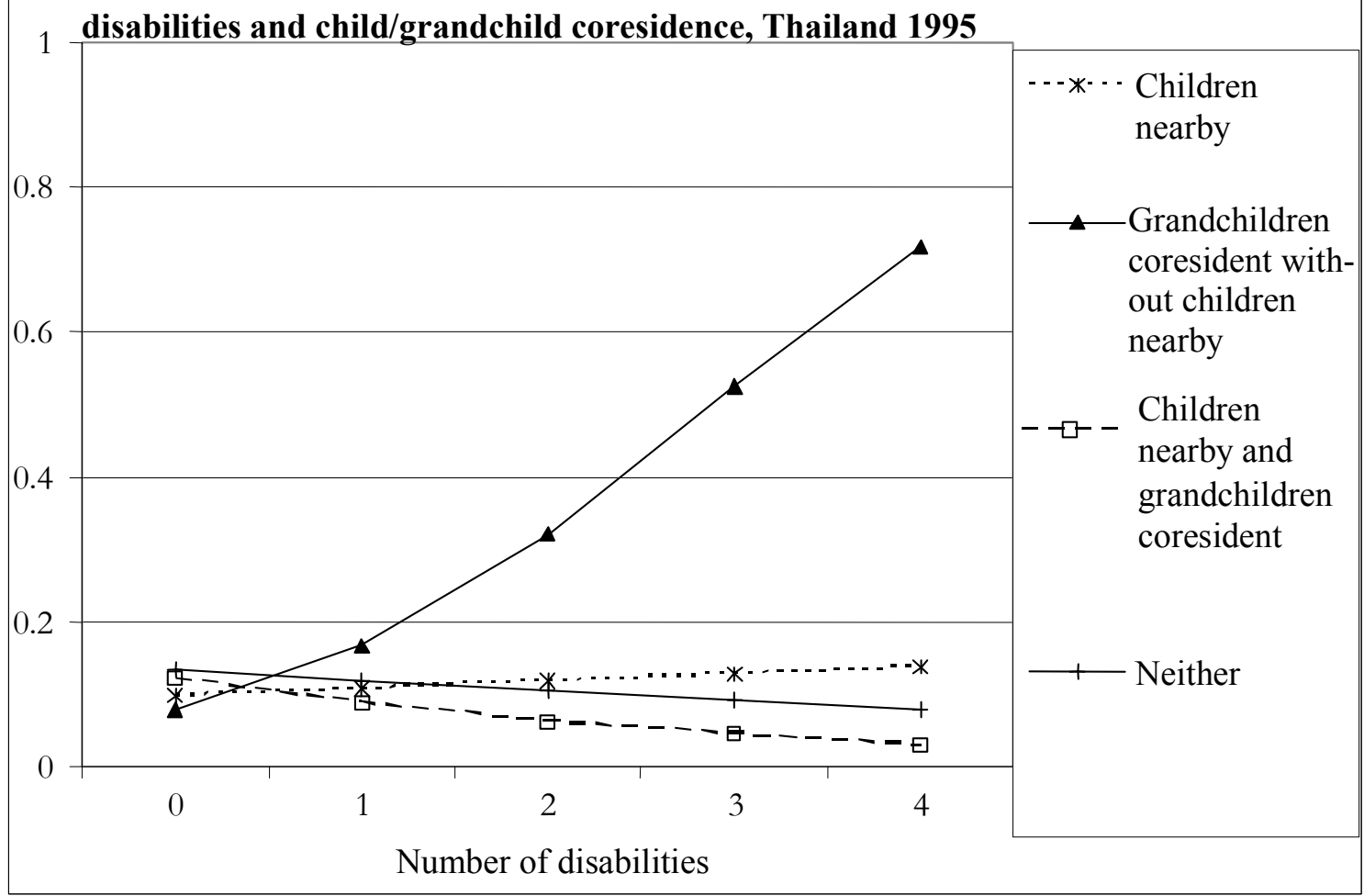


\section{Poverty, Gender, and Youth Working Papers}

If still in print, single copies of up to three working papers from 1989 through 2003 are available free of charge.

Beginning with the 2004 issues, working papers are no longer available in print format. Instead they are distributed electronically. As each new paper is completed, subscribers are notified by e-mail and a link to the paper is provided.

To subscribe to the Poverty, Gender, and Youth working paper e-mail notification list, or to obtain back issues from 1989 to 2003, please send your request to pgywp@popcouncil.org.

PDFs of recent issues are available at www.popcouncil.org/publications/wp/index.html

2007

2 Zachary Zimmer, Kim Korinek, John Knodel, and Napaporn Chayovan, "Support by migrants to their elderly parents in rural Cambodia and Thailand: A comparative study."

1 Sharon Ghuman and Cynthia B. Lloyd, "Teacher absence as a factor in gender inequalities in access to primary schooling in rural Pakistan."

\section{Policy Research Division working papers}

\section{6}

219 Cynthia B. Lloyd and Barbara S. Mensch, "Marriage and childbirth as factors in school exit: An analysis of DHS data from sub-Saharan Africa."

218 Ayaga A. Bawah, James F. Phillips, Martin Adjuik, Maya VaughanSmith, Bruce MacLeod, and Fred N. Binka, "The impact of immunization on the association between poverty and child survival: Evidence from Kassena-Nankana District of northern Ghana."

217 Zachary Zimmer, "Poverty, wealth inequality, and health among older adults in rural Cambodia."
216 John Bongaarts, "Late marriage and the HIV epidemic in sub-Saharan Africa."

215 John Bongaarts, "How long will we live?"

214 Zachary Zimmer, Toshiko Kaneda, and Laura Spess, "Urban versus rural mortality among older adults in China."

213 Paul Demeny and Geoffrey McNicoll, "The political demography of the world system, 2000-2050."

212 Monica Grant and Kelly Hallman, "Pregnancy-related school dropout and prior school performance in South Africa."

211 Kelly Hallman, Sara Peracca, Jennifer Catino, and Marta Julia Ruiz, "Multiple disadvantages of Mayan females: The effect of gender, ethnicity, poverty, and residence on education in Guatemala."

210 Geoffrey McNicoll, "Policy lessons of the East Asian demographic transition." 
Brian Wells Pence, Philomena

Monica J. Grant, "The implications of Nyarko, James F. Phillips, and changing educational and family circumstances for children's grade progression in rural Pakistan: 19972004."

\section{5}

James F. Phillips, Ayaga A. Bawah, and Fred N. Binka, "Accelerating reproductive and child health program development: The Navrongo

Initiative in Ghana."

207 John Bongaarts and Griffith Feeney, "The quantum and tempo of lifecycle events."

206 Barbara S. Mensch, Monica J. Grant, and Ann K. Blanc, "The changing context of sexual initiation in subSaharan Africa."

205 Geoffrey McNicoll, "Population and sustainability."

204 John Bongaarts, "The causes of stalling fertility transitions."

203 Ayaga A. Bawah and Fred N. Binka, "How many years of life could be saved if malaria were eliminated from a hyperendemic area of northern Ghana?"

202 Barbara S. Mensch, Susheela Singh, and John B. Casterline, "Trends in the timing of first marriage among men and women in the developing world."

Zachary Zimmer, "Active life expectancy and functional limitations among older Cambodians: Results from a 2004 survey." 